\title{
Private Wrongs of Public Servants
}

\author{
R.J.Gray* \\ "O! It is excellent \\ To have a giant's strength; but it is tyrannous \\ To use it like a giant. ..." \\ William Shakespeare, Measure for Measure, Act II, Scene 2.
}

The problems of tort liability arising from activities of persons who serve the state have been far from successfully answered by the common law. Roots stretching out from ancient times have tripped twentieth century courts in their efforts to reach the practical solutions needed in an age where state activities dominate society and a large percentage of the working population falls, in one sense or another, into the category of "persons who serve the state."

Unfortunately, even where courts have discovered injustices and decried them, but have felt bound through the pressure of centuries old decisions to declare themselves unable to remedy the situation, ${ }^{2}$ timid legislators, wearing a psychological straitjacket, have, except in haphazard instances, ${ }^{3}$ been similarly unwilling to act. Thus there exists the umique

* Member, Ontario Bar; Lecturer, Osgoode Hall Law School, Toronto.

1 For example, in the Umited States in 1957 , approximately $16 \%$ of the working force was employed by some level of government. Of $67,000,000$ employed, in all occupations, 2.8 millions were in the armed services, 2.4 millions in federal civil employment, 1.3 millions in state government jobs, and 4 millions worked in local government capacities-a total of 10.5 million persons serving the state in the United States. See 1958 WordD ALMaNac 75, 259; 1958-59 The BoOK OF THE States 148.

2 See Scrutton, L.J., in Mackenzie-Kennedy v. Air Council, 96 L.J. Ch. 470,479 (C.A. 1927), referring to the difficulties besetting a plaintiff attempting to sue the government, "[These] proceedings ... are thoroughly discreditable to the English Constitution. ... [T] Government makes up their minds . . to simplify the procedure . . . the better for everybody concerned." And see, in Adams v. Naylor, [1946] A.C. 543, 553, 555 (H.L.), commenting on the necessity of ending the Crown's immunity from tort liability, Ld. Simmons, "Iong overdue," and Ld. Uthwatt, "[T]he increasing activities of the state . . . make the matter urgent." See also Scott, L.J., in Royster v. Cavey, [1947] K.B. 204, 210, "[I]t will be a crying wrong if that legislation is not introduced at an early date ...." These latter two decisions are generally credited with spurring Parliament into action resulting in the Crown Proceedings Act, 1947, $10 \& 11 \mathrm{Geo} .6$, c. 44 , which to a considerable extent removes the Crown's immunity from liability for the acts of its servants.

3 A minority of Anglo-American jurisdictions have now passed general statutes providing state liability for tortious acts of state servants. See note 14 infra. These acts liave broad exceptions, and ignore entirely the problem of non-tortious injury. A rare example of a general statute providing compensation for such injury is the "damages for unjust convictions" section of the U.S. Code, 28 U.S.C. $\$ \S 1495,2513$ (1952), which allows persons erroneously found guilty of crime by federal courts and cleared later after a period of incarceration to claim damages up to $\$ 5000$. A few states lave comparable legislation (e.g., CaI. PEN. CODE $\$ 4900$ ). All jurisdictions have piecemeal statutory exceptions to the rule of strict governmental immunity for tort. See Leflar \& Kantrowitz, Tort Liability of the States, 29 N.Y.U. L. Rev. 1363 (1954); Jamieson, Proceedings by and Against the Crown in Canada, 26 CAN. B. Rev. 373, 383 (1948). 
gap in Anglo-American law which leaves the victim of non-tortious, yet grossly harmful, acts of the state or its officials, with no right of recovery whatsoever. The prisoner who serves five years of a conviction before another confesses to the crime; ${ }^{4}$ the roadside entrepreneur who is suddenly destroyed when a highway improvement does away with both his bend and his business; ${ }^{5}$ the householder whose home is flooded while the fire department extinguishes the blaze next door ${ }^{6}$ the citizen whose city is demolished when the ammunition ship in the harbour explodes, ${ }^{7}$ are inevitable casualties of the risks of organized society, not of any culpable individual. But lacking an actor on whom to pin their misfortunes, they are met by the common law with a "breaks of the game" philosophy, which requires them as individuals to bear the exceptional loss they have suffered at the hands of the state in its attempt to function for the benefit or convenience of all the citizens.

Obviously, the financial condition of the state requires limitations at some point short of perfection in any policy of restoring individuals for state inflicted injuries. But it is equally obvious that that limit is not approached under the present policies of most Anglo-American jurisdictions. Our legislatures, while reacting generously by the clumsy method of special statutes in numerous specific cases, ${ }^{8}$ have been unable or unwilling to provide

4 For an interesting example of this situation, see Hoffner v. State, 207 Misc. 1070, 142 N.Y.S.2d 630 (Ct. Cl. 1955), where the innocent plaintiff served 12 years on a murder conviction before being exonerated. Fortunately, New York being one of the few Anglo-American jurisdictions with statutory provision for compensation in such cases, Hoffner was able to recover a sizeable judgment. See, however, Borchard, Convactinc THE INNOCENT (1932); Frant \& Frans, NoT GuIITY (1957); and Borchard, State Indemnity for Errors of Criminal Justice, 21 B.D.L. REv. 201 (1941), for instances where the victin was not so lucky.

5 "Loss of trade or custom, by reason of a [public] work ... is not by itself a proper subject for compensation. . . " Per Ld. Selborne in Caledonian Ry. v. Walker's Trustees, 7 App. Cas. 259, 276 (1882). "The interference here complained of must be shouldered by the plaintiffs as one of the inconveniences to be borne by the individual for the larger benefit of the community and the public in general." Cities Service Oil Co. v. City of New York, 5 N.Y.2d 110, 154 N.E.2d 814 (1958). Cf. Metropohtan Bd. of Works v. Howard, 5 T.L.R. 732 (H.L. 1889), affirming 4 T.L.R. 591 (C.A. 1888). See also Hopkins v. Great Northern Ry., 2 Q.B.D. 224 (C.A. 1877).

6 Street, Governacentar Liabitity 78 (1953). See also Dunbar v. The Alcalde, 1 Cal. 355 (1850); Russell v. The Mayor of New York, 2 Denio 461 (N.Y. 1845); Cope v. Sharpe, [1912] 1 K.B. 496 (C.A. 1911).

7 Dalehite v. United States, 346 U.S. 15 (1953). See Schwartz, Public Tort Liability in France, 29 N.Y.U.L. REv. 1432 (1954), contrasting the U.S. and French results, with respect to governmental liability, im sueh a situation.

8 The legislature by special act either waives the state's immunity from suit in the case of a named plaintiff, or, deciding the merits itself, compensates the claimant directly. For examples of the former, see Tolisano v. State, 19 Conn. Supp. 26t, 111 A.2d 562 (Super. Ct. 1954); Campbell v. State, 186 Misc. 586, 62 N.Y.S.2d 638 (Ct. Cl.1946); of the latter, see Davis, Tort Liability of Governmental Units, 40 MrNo. L. REv. 751 (1956) ; Gellhorn \& Lauer, Con-gressional Settlement of Tort Claims Against the United Slates, 55 CorUM. L. REv. 1 (1955); Gellhorn \& Lauer, Federal Liability for Personal and Property Damage, 29 N.Y.U.I. REv. 1325, 1328-42 (1954); Leflar \& Kantrowitz, Tort Liability of the States, 29 N.Y.U.L. REv. 1363 (1954) 
any systematized method of recovery in these situations. Instead, the line is presently, and apparently will continue for the forseeable future, frozen at a purely historical point which requires an official miscreant before the law offers even any hope of recovery.

Perhaps the best example of the lethargy of legislatures in remedying the defects of the common law in this area is the still partial development, after forty years of active agitation, ${ }^{0}$ of governmental tort liability acts. The ancient maxim that "the King can do no wrong" was and is the keystone of the doctrine of soverign immunity. Unhappily after the passing from the Anglo-American scene of the omnipotent personal monarch, the concept was transformed to read that the crown or state can do no wrong nor, for that matter, authorize others to do wrong. Thus the state is not vicariously liable on ordinary agency principles for the acts of its servants.

However, the corollary of this proposition is that the servants of the state are each personally liable for their wrongful acts, as any other citizens would be. Dicey's claim that "every official, from the Prime Minister down to a constable or a collector of taxes, is under the same responsibility for every act done without legal justification as any other citizen"10 despite recent criticism, ${ }^{11}$ still, in the sense meant by Dicey, appears to stand the test of time in most jurisdictions throughout the common law world today.

The merits of this system which put a salutorily heavy onus on an official to act properly and carefully, mask several serious defects. The desirability of saddling some minor official with a damage judgment occasioned by a slight lapse from the reasonable man standard while engaged in activities designed to benefit the public at large, ${ }^{12}$ is clearly doubtful. But a much greater practical flaw in this system is the fact that the successful plantiff may often find that such a defendant is judgment proof. The injured individual, run down when the $\$ 4,000$ a year mail truck driver's judgment fails for a moment, finds little solace from the theoretic personal responsibility of governmental employees when he tries to collect

0 E.g., Borchard, Governmental Responsibility in Tort, 34 YaLe L.J. 1, 129, 229 (1924-25), 36 id. 1, 757, 1039 (1926-27), 28 ColuM. L. REv. 577, 734 (1928) ; Holdsworth, The History of Remedies Against the Crown, 38 L.Q. REv. 280, 295 (1922); Laski, The Responsibility of the State in England, 32 HARv. L. REv. 447 (1919). Brief accounts of the lingering legislative treatment accorded the English and United States acts may be found, respectively, in ArLEN, LAW AND ORDERs 356 (2d ed.1956) and Borchard, Governmental Liability in Tort, 26 CAN. B. Rev. 399 (1948).

10 Dicey, The Law of tere Constitution 193 (9th ed. 1939). "The civil irresponsibility of the supreme power for tortious acts could not be maintained with any show of justice, if its agents were not personally responsible for them ...." See Rogers v. Rajendro Dutt, 13 Moo. P.C. 209, 236, 15 Eng. Rep. 78, 89 (1860).

11 Davis, Administrative Officers Tort Liability, 55 MICH. L. REv. 201, 202 (1956).

12 "The errors I make are made in the interest of the taxpayers." Reeve Tonks, Metropolitan Toronto Council, Toronto Globe \& Mail, March 13, 1958, p. 7, "Refreshing Originality." 
his $\$ 10,000$ judgment. The purpose of the tort liability acts has been to insert, for the benefit of the injured plantiff, the financial responsibility of the state behind the governmental tortfeasor. The merits of such a policy have been so often discussed and recognized that there is no need for expansion here. ${ }^{13}$ Suffice it to say, that a majority of jurisdictions throughout the common law world still resist general legislation of this type. ${ }^{14}$

This paper is not intended to present a discussion of the highly complicated problems of how far and by what method governmental liability should be extended. ${ }^{15}$ What has been intended by these preliminary remarks is to demonstate that in Anglo-American law when a person who serves the state injures another while acting in his official capacity, the focus of liability is presently on the tortfeasor-officer personally, not the state, and that no legislative revolution in this respect appears imminent. Thus in jurisdictions which have adopted some type of governmental liability, the statutes are without exception phrased or interpreted in terms of the government being liable only if the servant involved would have been personally liable apart from the statute. ${ }^{10}$

With these considerations in mind, an examination of the common law pertaining to the torts of officials takes on added value. Endeavoring to show just who is liable for what, within the area of officially dealt harms, is the purpose of this paper. To do so will involve exploring venerable dogmas and investigating their effect on the present day liability of officials. Why some officials, contrary to the general rule, are immune from personal liability requires examination. Language difficulties which beset this area of the law with a bewildering array of terms-judicial, discretionary, ministerial, governmental, immunity, privilege-will, it is hoped, receive some incidental sorting out.

The approach will be to survey the position with respect to tort liability of the head of state, the judge, the legislator, and, in particular, the administrator, in both English and American jurisdictions. Certain gen-

${ }^{13}$ See StreEt, Governmentax LIABITITy (1953), for a concise but comprehensive recent treatment of this subject.

14 While the governments of the United Kingdom, the United States, Canada, New Zealand, Australia and all the Australian states are now generally subject to tort liability, only one American state (New York) and four Canadian provinces (Manitoba, New Brunswick, Nova Scotia and Saskatchewan) present more than a patchwork picture of liability. See note 3 supra.

15 See Street, Governarental LIABIITTY 76 (1953) for suggestions.

16 E.g., England: "[T]he Crown shall be subject to all . . . liabilities in tort . . . in respect of torts committed by its servants or agents ... provided ... any act ... of a servant or agent ... would .. have given rise to a cause of action in tort against that servant or agent ...." Crown Proceedings Act, 1947, 10 \& 11 Geo. 6, c. 44, \$2(1). United States: The United States shall be liable "for the negligent or wrongful act . . . of any employee of the Government ...." Federal Tort Liability Act, 60 Stat. 842 (1946), 28 U.S.C. $\$ \$ 1376,2674$ (1952). New York: "The state hereby waives its immunity" "for the torts of its officers or einployees. . ." Court of Claims Act $\S \S 8,9(2)$. 
eral theories will be advanced, and several specific problems considered in some detail. However, the scope of the topic is of such breadth that, regretfully, but necessarily, certain problems of current interest in this area -for example, the questions of jurisdictional facts, of excess of power and administrative officers, of the liability of public officers for acts done pursuant to ultra vires statutes, and of the effect of the riglit of official litigants to refuse to disclose documents or information when exposure would not be "in the public interest"-are virtually ignored.

\section{The Head of State}

In its personal sense, the rule that "the King can do no wrong"17 left over from the days of the Divine Right of Kings-exists today to give the Queen an absolute immunity from being sued for personal torts in the civil courts. This anomaly has been carefully preserved by the Crown Proceedings Act, ${ }^{18}$ and is undoubtedly justified practically, apart from sentimental, traditional reasons. The function of the titular head of state is, after all, to present a perfect reflection of the state and its virtues both to itself and to the world at large. To have the petty wrongs of the person holding this office paraded through the courts would be entirely destructive of the purpose for which such an office exists.

The actual effect of this immunity is, of course, practically nil. No modern ${ }^{19}$ cases exist where an unsuccessful attempt has been made to sue the soverign personally for tort, probably not because occasions have not arisen in which such an action would have been appropriate, but because injuries so sustained have been compensated for as a matter of grace. This immunity extends to the persons of the sovereign's immediate household as long as they continue so to be, ${ }^{20}$ unless the sovereign waives the immunity. The latter rule existed historically to safeguard the sovereign's personal convenience, ${ }^{21}$ a rather unsatisfactory justification in a modern democracy.

17 See 1 Blacrstone, CoMrarentarIes, 246-47 (Jones ed. 1915): "[T] he law ascribes to the king, in his political capacity, absolute perfection. The king can do no wrong .... Moreover [he] is not only incapable of doing wrong, but even of thinking wrong; he can never mean to do an improper thing; in him is no folly or weakness. ..."

18 Crown Proceedings Act, 1947, 10 \& 11 Geo. 6, c. 44, § 40(1).

19 For one of the more recent cases, see Viscount Canterbury v. Atty. Gen., 1 Ph. 306, 321, 41 Eng. Rep. 648, 654 (Ch. 1843), per Ld. Lyndhurst: "It is admitted that, for the personal negligence of the Sovereign, neither this nor any other proceedings can be maintained. ..."

$20 \mathrm{~A}$ comparable privilege is afforded foreign diplomats and their households. This exemption from the jurisdiction of local courts for diplomats' private acts, may be waived by the foreign government, and in any event, ends with the termination of their diplomatic character. See Briggs, The Law of Nations 761-87 (2d ed. 1952). Various rationale have been suggested, but surely the basis of this privilege is, again, functional, i.e., the diplomat's raison d'etre is principally to represent the sovereign dignity of the other state. This dignity should not easily be demeaned.

21 See Iuntley v. Battine, 2 B. \& Ald. 234, 106 Eng. Rep. 353 (K.B. 1818). 
Whether a comparable privilege extends to persons such as governorgenerals and lieutenant-governors who, under Commonwealth constitutional concepts fulfill the function of the sovereign, acting as personal representatives of the Queen in the various jurisclictions of the Commonwealth, is not clear. Although not the case with the governor in the colonial era who served not only in a symbolic capacity but also as the principal executive and military officer of his jurisdiction, ${ }^{22}$ in the absence of authority, a guess would be that, today, such persons filling the exact role of the sovereign, are, similarly, beyond the reach of courts during their term of office.

The duties of the President of the United States require him to be both the personification of national sovereignty and the chief executive officer of the nation. The silence of a century and a half of cases seems to indicate that the President while in office is immune from actions for tortious conduct. While one line of cases, which will be discussed later, might suggest another basis of non-liability for lis official acts, ${ }^{23}$ the only explanation which satisfies as to why lie is not sued for delicts occuring in the personal portions of his life as distinct from his official life is that he, in lias capacity as titular liead of state, in consonance with the symbolic function of his office, inust be exempt from the reach of the courts ${ }^{24}$ as is the British sovereign. Althougl the President has, in practice, much greater opportunity than the Queen to inflict harm by personal conduct, the real effect of such an immunity is very slight, and undoubtedly tempered by the generosity of the presidential conscience. However, if this is the correct conceptual basis, there is no reason why this immunity, though necessary while he is in office for acts occurring before and during his term, should extend beyond the conclusion of this term. Thus an uncompensated plaintiff should be entitled to bring his action once the President has given up the office. ${ }^{25}$

22 See Mostyn v. Fabrigas, 1 Cowp. 161, 98 Eng. Rep. 1021, 1029 (K.B. 1775) (Minorca, arbitrary banishment order), per Ld. Mansfield: "such a inonstrous proposition, as that a governor . . . is accountable only to God, and his own conscience . . . cannot be maintained. . .." See also Musgrave v. Pulido, 5 App. Cas. 102 (P.C. 1879) (Jamaica, detention of slip); Phillips v. Eyre, L.R. 6 Q.B. 1 (1870) (Jamaica, false imprisonment); Wall v. McNamara (1779) (Gambia, false imprisonment) and Sutherland v. Murray (1733) (Minorca, malicious statement), cited in Johnstone v. Sutton, 1 T.R. 511, 536, 539, 99 Eng. Rep. 1225, 1239-40 (K.B. 1786).

23 I.e., that as a high executive officer, he is either constitutionally or at American common law immune for acts done in the performance of his office. See text at notes 42-52 infro.

24 For a discussion of the history of presidential right of immunity from subpoena, sce Corwin, The President-Office and Powers 112, 325-28 (1957).

25 The case of Livingston v. Jefferson, 15 Fed. Cas. 660 (No. 8411) (C.C. Va. 1811), contained the elements of this problem. The action, brought after Jefferson had completed his term of office in 1810, involved an alleged trespass to land in Louisiana three years earlier, ordered by Jefferson in the course of his presidential duties. Unfortunately, the Circuit Court (Marshall C.J.) found a lack of jurisdiction (the action should have been brought in Louisiana). However, the court gives the impression that it would have decided the matter on the merits if jurisdiction had been estabished. Jefferson's defence was not that of immunity but that he had acted in his capacity as President without malice. 
In theory, state governors are in almost the exact position vis-à-vis the state that the President is, with respect to the nation. It is a practical fact, however, that to the general public a governor is identified, in comparison with the President, as much more the executive and political leader than as a symbol of state sovereignty. Therefore, there is little functional or psychological need to portray governors, for the sake of state honor, as unblemished and unblemishable. So, it is not suprising to discover several modern cases $^{26}$ which clearly indicate that in the proper circumstances a governor is subject to tort liability during his term in office. The courts emphasize that while he is not answerable for any acts for which he has lawful authority, his duties do not extend to breaking the law, and that when he steps outside it, he is suable as any individual.

\section{JUUdes AND COURTS}

The law relating to judges is at the root of many of the problems afflicting the law of officer's tort liability. The judge has truly been the pampered child of the law, ${ }^{27}$ for he is among those privileged few who are allowed to fulfill their duties not only stupidly, or negligently but wilfully, maliciously, corruptly or just plain dishonestly, yet escape liability to those damaged by his conduct. A cynic might be forgiven for pointing out just who made this law. However, it would be to give the judges much less than their due to suggest that self-protection is the clue which explains the theory of judicial immunity.

Before attempting an explanation of this special status, it is wise to note there are limits to it. First of all it is not the personal immurity of the King, who is in fact absolutely immune from the reach of the courts for any and all tortious conduct. Rather the privilege of the judge extends only to acts done in his judicial capacity. So if, on the street, he punclies a citizen in the nose, or runs him down in his automobile, if he has another maliciously prosecuted, ${ }^{28}$ or if he keeps a leaky dam that floods lis neighbor, ${ }^{29}$ the judge, unlike the King, will be liable for damages. Second, even if he is acting in a judgelike capacity, the matter of jurisdiction may arise, depending on what category of judge he be, to dilute his immumity. ${ }^{30}$

20 See Ryan v. Wilson, 231 Iowa 33, 300 N.W. 707 (1941); Hatfield v. Graham, 73 W.Va. 759, 766, 81 S.E. 533, 535 (1914); Ekern v. McGovern, 154 Wis. 157, 217, 142 N.W. 595, 607, 611 (1913).

27 "[T]hat privileged order is protected by peculiar, inherent and unquestioned privileges. ..." Per Ld. Norbury, Taaffe v. Downes, 13 Eng. Rep, 15, 33 (C.P. 1813).

28 Stewart v. Cooley, 23 Minn. 347, 23 Am. Rep. 690 (1877) ; State v. Umited States Fidelity \& Guaranty Co., 217 Miss, 576, 64 So.2d 697 (1953).

29 See the San Francisco Chronicle, March 25, 1958, p. 9 ; March 26, 1958, p. 1.

30 See Bradley v. Fisher, 80 U.S. (13 Wall.) 335,351 (1871); Farish v. Smoot, 58 So.2d 534 (Fla. 1952); Cox v. Perkins, 299 Ky. 470, 185 S.W.2d 954 (1945); Houlden v. Smith, 14 Q.B. 841, 117 Eng. Rep. 323 (1850) ; Marshalsea Case, 10 Co. Rep. 68b, 77 Eng. Rep. 1027 (K.B. 1612). And see text following note 64 infra. 
Finally, while it is little solace to the individual injured thereby, the judge is open to possible criminal prosecution and liable to impeachment or removal for his mala fide or corrupt acts. ${ }^{31}$

However, it is ordinarily a complete answer to a complaint charging tortious conduct to a judge for him to answer, " $I$ am a judge and the act complained of was done while I acted as a judge within my proper jurisdiction." 32 Suggested rationale of this sweeping immunity are numerous. Prof. Edward Jennings' leading article ${ }^{\mathbf{3}}$ suggests no less than nine reasons that have combined to establish it. ${ }^{34}$ Yet, none are truly satisfactory as explanations of why a person alleging injury by a corrupt act should be barred from compensation without any consideration on the merits of the case.

\section{A. Explanations of Judicial Immunity}

The difficulty stems from the disguised dual nature of the judge's immunity. On the one had, is the obvious justice that a man should not be liable for a mistaken opinion, honestly given, when the very nature of his position requires the giving of that opinion..$^{35}$ Truly, a man would have to be "a beggar or a fool"38 to be a judge under such circumstances.

It is easy to agree that no personal liability should lie for innocent errors in judgment, nor is there any indication in the cases that judges ever have been subject to liability for this type of injury. By definition, the world over, judges, acting within their jurisdiction, are allowed an honest mistake. But the explanation of immunity for corrupt acts is a distinct and different matter, hanging by an ancient thread that is as out of place in the

31 Judges' tenure is usually "during good behavior"-whatever that is. See U.S. Const. art. III, § 1; England, Supreme Court of Judicature (Consolidation) Act, 1925, $15 \& 16 \mathrm{Geo} .5$, c. $49, \S 12$ (1) ; Canada, Br. North America Act, 1867, 30 \& 31 Vict. c. $3,99$.

There are various methods of effecting removal of judges from office. In England, the method is by petition of both houses of Parliament to the Queen. In the United States, federal judges are removable on impeachment by Representatives, conviction by the Senate. See, respectively, for American and Commonwealth methods, 48 C.J.S., Judges \$ 27, and 5 HaLsbury's LaWs of ENGLaNd, Commonwealth $\$ \$ 1430-33$ (3d ed. Simonds 1953).

32 See Haggart's Trustees v. Lord President (Miller v. Hope), 2 Shaw Scot. App. 125 (H.L. 1824); Yates v. Lansing, 5 Johns. R. 282, 284 (N.Y. Sup. Ct. 1810); Mostyn v. Fabrigas, 1 Cowp. 161, 171, 98 Eng. Rep. 1021, 1027 (K.B. 1775).

33 Tort Liability of Administrative Officers, 21 MrNv, L. REv. 263 (1937).

34 Id. at 271-72. Briefly, the suggested reasons are: saving judges' time, preventing influence on decisions through fear of subsequent suit, removing a discouragement to judicial service, separation of powers, necessity of finality, other opportunities for review of adverse decisions, duty lying to public only, not individuals, judicial self-protection and unfairness in penalizing honest error.

35 Though, of course, the state might conceivably offer compensation in such circumstances.

36 Haggart's Trustees v. Lord President (Miller v. Hope), 2 Shaw Scot. App. 125 (H.L. 1824), per Ld. Robertson at 134. 
cloth of modern democracy as the theory of sovereign immunity of government has recently been discovered to be.

Coincidentally, both theories have common ancestry. Since the King could do no wrong, his personal delegates, the judges, to whom he had entrusted the dispensing of justice throughout the realm "ought not to be drawn into question for any supposed corruption [for this tends] to the slander of the justice of the King. ${ }^{\prime 37}$ Because the judges were the custodians and guardians of the King's oath to deliver justice to all his subjects, injustice of judges concerned the honor and conscience of the King. Thus, "there was great reason that the King himself should take account of it, and no other."38 Moreover, the judges sat in the Curia Regis, the King's house. There, in law, the King was ever present. Anything done in the sight of the King must be deemed always pure, for to say otherwise was to asperse the purity of the King. ${ }^{39}$

Such reasoning was hardly acceptable to post-Revolutionary America, or for that matter, nineteenth century England. Yet several hundred years of precedent stood behind the concept. ${ }^{40}$ Chancellor Kent solved the impending dilemma in favor of tradition by finding in Yates v. Lansing ${ }^{41}$ in an oft quoted paragraph that "whenever we subject the established courts ... to the degradation of private prosecution, we subdue their independence, and destroy their authority."42 Thereafter variations of this theme replaced the sanctity of the King's honor as the justification of judicial in1Inunity, completely eclipsing the historic rationale, in English as well as American decisions. ${ }^{43}$ The modern explanations suffer from being merely ex post facto.

For better or for worse, however, the Anglo-American law is wedded to the proposition that public convenience requires public sufferance of corrupt judicial officers for the sake of the independence and efficiency of the honest vast majority. In a rare ${ }^{44}$ but classic criticism, Chief Justice Cockburn flailed this whole doctrine in his dissent in Dawkins v. Lord Paulet. ${ }^{45}$

37 Floyd v. Barker, 12 Co. Rep. 23, 25, 77 Eng. Rep. 1305, 1307 (Star Chamber 1607).

38 Ibid.

39 See 1 Blackstone, ComomentarIes 270 (Jones ed. 1915). "His judges are the mirror by which the king's image is refiected."

40 See 26 Hatsbury's Laws of England, Public Authorities $\$ 587$ n.(d) (2d ed. Hailsham 1937) for a list of the ancient authorities.

415 Johns. R. 282 (N.Y. Sup. Ct. 1810).

42 Id. at 298 .

43 E.g., Bradley v. Fisher, 80 U.S. (13 Wall.) 335 (1871); Booth v. Fletcher, 101 F.2d 676 (D.C. Cir. 1938) ; Bottomley v. Brougham, [1908] 1 K.B. 584; Scott v. Stansfield, L.R. 3 Ex. 220 (1868); and see Jennings' explanations, note 34 supra.

44 But see also Kintz v. Harriger, 99 Ohio St. 240, 124 N.E. 168 (1919), per Wanamaker, J. 45 L.R. 5 Q.B. 94 (1869). 
"For my own part" he stated "I should prefer to treat the immunity of judges as a matter of positivi juris, as settled by decision and precedent, rather than as resting on sound or satisfactory principles, on which, were the matter res integra, it would be desirable to act. I cannot believe that judges or juries would fail to discharge their duty faithfully and fearlessly according to their oaths and consciences, or witnesses give evidence any less truthfully, from any fear of exposing themselves to actions at law. I am persuaded that the number of such actions would be infinitely small and would be easily disposed of. While, on the other hand, I can easily conceive cases in which judicial opportunity might be so perverted and abused for the purpose of injustice as that, on sound principles, the authors of such wrong ought to be responsible to the parties wronged." 48

It is, surely, not admissable for a judicial system dependent upon the jury, to answer this criticism by saying juries make mistakes. Though trite to repeat, it is nonetheless true, that juries have been entrusted often with men's lives, let alone a judge's honor or pocket book. In any event, the deciding of honesty of motive is one thing at which, it is usually conceded, juries excel. ${ }^{47}$

However, this is a windmill at which further tilting is undoubtedly futile. The purpose of such a lengthy exposition of this well-settled point of law is to emphasize that the explanation of the complete judicial freedom from action for alleged misdeeds is largely historical. It is necessary to keep this point in mind when examining a disturbing line of American cases dealing with a different type of official which will be discussed later. ${ }^{48}$

\section{B. Who is Entitled to It}

All the essential participants in the judicial drama are allowed to claim this immumity, which it must be stressed, includes civil non-liability not only for honest error but also for non bona fide acts as well. Judges, from the supreme court variety ${ }^{49}$ down through magistrates ${ }^{50}$ and justices of the

46 Id. at 110.

47 Id. at 109.

48 See text at notes 197-245 infra.

49 Haggart's Trustees v. Lord President (Miller v. Hope), 2 Shaw Scot. App. 125 (H.L. 1824) (President of the Scottish Ct. of App.); Allen v. Eiggs, 62 F. Supp. 229 (E.D. Pa. 1945) (Senior Judge, 3d Cir. Ct. of App.) ; Francis v. Branson, 168 Okla. 24, 31 P.2d 870 (1934) (Justice of the Supreme Ct. of Okla.); Taaffe v. Downes, 3 Moo. P.C. 36, 13 Eng. Rep. 15 (C.P. 1813) (Chief Justice of Ireland) ; Dicas v. Baron Brougham, 1 M.\&R. 309, 174 Eng. Rep. 106 (N.P. 1833) (Ld. Chancellor of England) ; Anderson v. Gorrie [1895] 1 Q.B. 668 (C.A. - 1894) (Supreme Ct. of Trinidad).

The recent California case of Rev. Mother Pauline v. Bray, 168 A.C.A. 462, 335 P.2d 1018 (1959), has reaffirmed the immunity of judges from civil action. Justice Bray was alleged to 
peace $^{51}$ have been held so entitled. Jurors, both petty ${ }^{52}$ and grand, ${ }^{53}$ witnesses ${ }^{54}$ and counse ${ }^{55}$ have been afforded similar privilege for their acts or words in court. ${ }^{56}$ The public prosecutor, ${ }^{57}$ a figure whose name is recognizable but whose function is unfamiliar to the legal systems of Commonwealth countries, has been accorded judicial immunity by some United States courts whenever he performs in the role of a grand jury. ${ }^{58}$

have decided a previous case against the plaintiff for reasons of malice and personal spite. The plaintiff claimed the value of the previous action as damages. Her action was dismissed without reference to the merits.

50 Shampagne v. Keplinger, 78 Mont. 114, 252 Pac. 803 (1927); Calder v. Halkett, 3 Moo. P.C. 28,13 Eng. Rep. 12 (1840) (India).

51 Everett v. Griffiths, [1921] 1 A.C. 631 (H.L.) ; Cooke v. Bangs, 31 Fed. 640, 642 (C.C.D. Minn. 1887); Grove v. Van Duyn, 44 N.J.L. 654 (Ct. Err. \& App. 1882) ; Allen v. Holbrook, 103 Utah 319, 135 P.2d 242 (1943); Pease v. Chaytor, 3 B.\&S. 620, 122 Eng. Rep. 233 (K.B. 1863) ; Hitchen v. Phipps, 29 Vict. L.R. 422 (1903).

52 Bushell's Case, 6 State Tr. 999 (1670); Dunham v. Powers, 42 Vt. 1 (1869).

63 Y.B. Hil. 21 Edw. 3, pl. 16; Cawley v. Warren, 216 F.2d 74 (7th Cir. 1954); Turpen v. Booth, 56 Cal. 65, 38 Am. Rep. 48 (1880); O'Regan v. Schermerhorn, 25 N.J. Misc. 1, 50 A.2d 10 (1946) ; Floyd v. Barker, 12 Co. Rep. 23, 77 Eng. Rep. 1305 (K.B. 1607); cf. Rector v. Smith, 11 Iowa 302 (1860).

54 Hunckel v. Voneiff, 69 Md. 179, 14 Atl. 500 (1888); Wheeler v. Hager, 293 Mass. 534, 200 N.E. 561 (1936) ; MacCabe v. Joynt, [1901] 2 Ir. R. 115 (Q.B. 1900) ; Barratt v. Kearns, [1905] 1 K.B. 504 (C.A.); Seaman v. Netherclift, 2 C.P.D. 53, 46 L.J.Q.B. (n.s.) 128 (C.A. 1876); Henderson v. Broomhead, 4 H.\&N. 569, 157 Eng. Rep. 964 (Ex. Ch. 1859); Revis v. Smith, 18 C.B. 126, 139 Eng. Rep. 1314 (C.P. 1856) ; cf. Magelo v. Roundup Coal Min. Co., 109 Mont. 293, 96 P.2d 932 (1939). The latter two cases illustrate attempts of many American courts to confine this privilege to "relevant" or "pertinent" statements. However, Prosser points out [Prosser, Torts 608-09 (2d ed. 1955)] that the actual effect of this distinction from the English rule of immunity for any utterance is practically nil. For an entirely different approach, see Kintz v. Harriger, 99 Ohio St. 240, 124 N.E. 168 (1919).

65 Maulsby v. Reifsnider, 69 Md. 143, 14 Atl. 505 (1888); Matthis v. Kennedy, 243 Minn. 219, 67 N.W.2d 413 (1954); Ostman v. Brucre, 141 Mo. App. 240, 124 S.W. 1059 (1910); Munster v. Lamb, 11 Q.B.D. 588 (C.A. 1883). Once again, the U.S. jurisdictions, in line with early English authority [Hodgson v. Scarlett, 1 B. \& Ald. 232, 106 Eng. Rep. 86 (K.B. 1818)], attempt to require some minimal "relevancy" in the counsel's act or statement.

56 The inelusion of witnesses and, apparently, counsel within the privileged group is of a more recent vintage than that of other judicially connected persons. This is consistent with the historical perspective since a breach of oath by a witness, being a private person, did not reflect on the King's honour by causing a vicarious breach of his sworn duty to deliver justice. See Floyd v. Barker, 12 Co. Rep. 23, 25, 77 Eng. Rep. 1305, 1307 (1607) ; but cf. Damport v. Sympson, Cro. Eliz. 520, 78 Eng. Rep. 769 (K.B. 1599).

The protection this rule offers to perjurers has been given recent hearty endorseinent (though not without some derisive comment in the English journals) by Ld. Goddard in what was practically the swan song of the now retired Chief Justice's judicial pronouncements. See Hargreaves v. Bretherton, [1958] 3 All E.R. 122, 3 Weekly L.R. 463. This unimaginative decision has been followed promptly with no examination into its merits by a Canadian court. See Oak v. Frobisher, Ltd., 27 West. Weekly R. (n.s.) 594 (Sask. Q.B. 1959).

57 Alias the prosecuting, district, city or state attorney, or assistant Attorney General, among other assumed identities.

68 See text at notes $239-45,261-64$ infra, for a full discussion of the prosecutor's claim to immumity. 
Certain bodies who clearly do not fit within the traditional judicial hierarchy have by analogy been given this immunity. They are usually statutorily created bodies with procedure comparable to courts, exercising adjudicatory functions. So bankruptcy commissions, ${ }^{60}$ military tribunals, ${ }^{, 0}$ ecclesiastical courts, ${ }^{01}$ lunacy hearings, ${ }^{62}$ and many other boards of inquiry and commissions ${ }^{63}$ have been equated to courts, for purposes of granting immunity. The usual context in which this issue has been raised is as to whether the same absolute privilege which obtains for statements in court exists for alleged defamation uttered in the course of the proceedings of such a tribunal. Though no such trend is perceptible in American decisions-indeed, the converse may be true-the present tendency of the English and Commonwealth courts is to restrict any extension of this unusual immunity. ${ }^{\text {s4 }}$

\section{Jurisdiction}

The major limitation to the breadth of judicial immunity is the boundary of jurisdiction. To claim the protection of immunity, the court must

69 Adair v. Bank of America, 303 U.S. 350 (1938) ; Burr v. Smith, [1909] 2 K.B. 306 (C.A.).

${ }^{60}$ Darwkins v. Ld. Rokeby, 4 F.\&F. 806, 176 Eng. Rep. 300 (C.P. 1866) ; cf. Wright v. White, 166 Ore. 136, 110 P.2d 948 (1941).

61 Barratt v. Kearns, [1905] 1 K.B. 504 (C.A.) ; butt cf. Landis v. Campbell, 79 Mo. 433 (1883), for U.S. reservations as to extending this privilege to church courts.

62 Everett v. Griffiths, [1921] 1 A.C. 631 (H.L.); Brown v. Rudolph, 25 F.2d 540 (D.C. Cir.), cert. den., 277 U.S. 605 (1928); Jarman v. Offutt, 239 N.C. 468, 80 S.E.2d 248 (1954); Hodson v. Pare, [1899] 1 Q.B. 455 (C.A.).

63 Jones v. Kennedy, 121 F.2d 40 (D.C. Cir.), cert. den., 314 U.S. 665 (1941) (Security Exchange Comm'n); Wilson v. Hirst, 67 Ariz. 197, 193 P.2d 461 (1948) (state hospital bd. of review); Nickovitch v. Mollart, 51 Nev. 306, 274 Pac. 809 (1929) (naturalization proceedings); Sweeney v. Young, 82 N.H. 159, 131 Atl. 155 (1925) (school dist. discipline bd.); Lipton v. Friedinan, 152 N.Y.S.2d (Sup. Ct. 1956) (compensation referee); Alagna v. New York \& Cuba Mail S.S. Co., 155 Misc. 796, 279 N.X.S. 319 (Sup. Ct. 1935) (Federal Radio Commission); Hughes v. Bizzell, 189 Okla. 472, 117 P.2d 763 (1941) (hearing of state univ. bd. of regents); Reagan v. Guardian Life Ins. Co., 140 Tex. 105, 166 S.W.2d 909 (1942) (state insurance comm'n); Lilley v. Roney, 61 L.J.Q.B. (n.s.) 727 (1892) (discipline comm'n of law society); Pedley v. Morris, 61 L.J.Q.B. (n.s.) 21 (1891) (hearing before taxing master); Thomas v. Chirton, 31 L.J.Q.B. (n.s.) 139 (1862) (coroner's inquest); Kemp v. Neville, 10 C.B.N.S. 523, 142 Eng. Rep. 556 (C.P. 1861) (univ. chancellor's court); Slack v. Barr, 82 J.P. 91 (Ct. of Sess. 1918) (Scot.) (statutory wartime arbitration tribunal).

64 See O'Connor v. Waldron, [1935] A.C. 76 (P.C. 1934) (Can.) (Canadian combines investigation); Smith v. National Meter Co., [1945] 1 K.B. 543 (workmen's compensation referee) ; Collins v. Whiteway \& Co., [1927] 2 K.B. 378 (unemployment insurance court); Attwood v. Chapman, [1914] 3 K.B. 275 (license justices' hearing). The mere fact that a body has to decide questions "judicially" does not mean that its proceedings are such that this immunity ought to attach. "[T] proceedings are such as ought to be conducted with the fairness and impartiahty which characterize proceedings in Courts of justice, ... not that the members of the body are members of a court. ... [I]t is not every discretion that is judicial. ..." Per Fry, L.J., in Royal Aquarium v. Parkinson, [1892] 1 Q.B. 431, 447, 448 (C.A.). It would appear that in Commonwealth jurisdictions absolute privilege will attach in the future only to bodies with strong historical claims to being a court. 
have been acting within its jurisdiction. ${ }^{65}$ Every court has some territorial limit to its jurisdiction. ${ }^{66}$ Most lave certain qualitative limits, for example, persons, ${ }^{67}$ matters ${ }^{88}$ or money values ${ }^{69}$ with respect to which they can properly concern themselves. In many instances competency depends on the fulfillment of a particular condition precedent. ${ }^{70}$ Again a court may meet all these requirements, yet endeavor to exercise a power which courts as such do not have. ${ }^{71}$ The effect of lack of jurisdiction is to nullify completely both facets of the judicial immunity of the actors, that is, as to honest but mistaken acts as well as to dishonest and nualicious ones. ${ }^{72}$ The judge thus becomes hable as a private individual would for any torts his acts might constitute. If this seems onerous, it should be recollected that under a system where the state refuses to bear the losses occasioned by the lionest errors of its officials, it is at least as equitable that the result of judicially inflicted injury should be borne by the judicial officer, at best, probably negligent in failing to take heed of a known boundary, as the entirely innocent citizen.

A more difficut policy question arises when a court is called upon to make preliminary findings as to the existence of the facts which give it jurisdiction, that is, where the "boundary" is unknown. It would be intolerable to put a judge in this position, and then lold him open to strict personal liability for an erroneous decision. ${ }^{73}$ Instead, a rule of reason applies and the judge retains his protection unless he knew or should have known of the non-existence of the fact or circumstance on which he pre-

65 See note 30 supre.

68 Cox v. Perkins, 299 Ky. 470, 185 S.W.2d 954 (1945).

67 Wise v. Withers, 7 U.S. (3 Cranch) 331 (1806); Calder v. Halkett, 3 Moo. P.C. 28, 13 Eng. Rep. 12 (1840); Houlden v. Smith, 14 Q.B. 841, 117 Eng. Rep. 323 (1850).

68 Farish v. Smoot, 58 So. $2 d 534$ (Fla. 1952); Rammage v. Kendall, $168 \mathrm{Ky} .26,181$ S.W. 631 (1916); O'Connor v. Isaacs, [1956] 2 Q.B. 288 (C.A.); Gwinne v. Poole, 2 Lut. 1560, 125 Eng. Rep. 858 (C.P. 1692); Marshalsea Case, 10 Co. Rep. 686, 77 Eng. Rep. 1024 (K.B. 1612).

69 King v. Lank, 44 Del. 189, 61 A.2d 402 (1948); Sullivan v. Jones, 68 Mass. (2 Gray) 570 (1854).

70 Beckham v. Cline, 151 Fla. 481, 10 So.2d 419 (1942); Hoppe v. Klapperich, 224 Minn. 224, 28 N.W.2d 780 (1947); Wood v. Fetherston, 27 Vict. L.R. 492 (1901); Hill v. Bateman, 2 Str. 710, 93 Eng. Rep. 800 (K.B. 1726) ; Beaurain v. Scott, 3 Camp. 388, 170 Eng. Rep. 1420 (C.P. 1813). Failure to meet insignificant precedent requirements is often ignored. See Tschuor v. Meck, 72 Ariz. 200, 232 P.2d 848 (1951); Singer v. Bogen, 147 Cal. App. 2d 515, 305 P.2d 893 (1957) ; Ackerley v. Parkinson, 3 M.\&S. 411, 105 Eng. Rep. 665 (K.B. 1815). Just where the line is drawn is not logically definable.

71 Vickrey v. Dumivan, 59 N.M. 90, 279 P.2d 853 (1955); Willis v. Maclachlan, 1 Ex. D. 376 (C. A. 1876).

72 Houlden v. Smith, 14 Q.B. 841, 117 Eng. Rep. 323 (1850).

73 "[Such a] doctrine ... is as unreasonable as it is impolitic. ... [I]t would thus involve in its liabilities all tribunals except those of last resort." Grove v. Van Duyn, 44 N.J. 654, 659 (Ct. Err. \& App. 1882), per Beasley, C.J. 
dicated his jurisdiction. ${ }^{74}$ Thus, what is sufficient jurisdiction to raise judicial immunity must always be distinguished from that on which an enforceable judgment can be based. ${ }^{75}$

\section{Justices of the Peace}

The justice of the peace or magistrate has historical and functional distinctions from the judge. Originally an administrative officer, ${ }^{76}$ he early acquired by statute many judicial duties, ${ }^{77}$ to the virtual exclusion of his administrative ones. However, his duties are not-and never were-purely judicial in nature. He also has certain functions usually termed ministerial. A ministerial act is one that the law requires him to perform once the person desiring him to perform has demonstrated the existence of certain conditions.

When acting as judge, the justice of the peace always has had the full benefiit of judicial immunity. ${ }^{78}$ But when acting as ministerial officer, he was hable to the person requiring him to act if he failed to act when all the conditions were fulfilled, and liable to any person injured if he acted when all the conditions were not met. For example, a justice of the peace has general jurisdiction to issue warrants. Upon certain circumstances being alleged, this duty is ministerial, i.e., he has no choice but to comply. However, say the allegations must be niade under oath if the warrant is to lie against a freeholder, but not so with respect to other persons. If the justice of the peace is nifornied that the person is a non-freeholder, and issues the warrant without oath, ${ }^{79}$ under English common law doctrines, he is liable to

74 Calder v. Halkett, 3 Moo. P.C. 28, 13 Eng. Rep. 12 (1840) ; Frazier v. Moffatt, 108 Cal. App.2d 379, 386, 239 P.2d 123, 127 (1951); Hodge v. Sharpe, 287 S.W.2d 596 (Ky. 1956); Grove v. Van Duyn, 44 N.J. 654 (Ct. Err. \& App. 1882); Doswell v. Impey, 1 B.\&C. 163, 107 Eng. Rep. 61 (K.B. 1823) ; Brittain v. Kinnaird, 1 Br. \& B. 432, 129 Eng. Rep. 789 (C.P. 1819).

This approach effectively tempers the rule of judicial non-immunity for acts done without jurisdiction, leaving liability only in cases where the officer has asserted wrongful jurisdiction intentionally, recklessly or neghigently.

Courts endeavour to distinguish between mistakes in fact and mistakes in law. See Houlden v. Smith, 14 Q.B. 841, 117 Eng. Rep. 323 (1850); Wood v. Fetherston, 27 Vict. L.R. 492 (1901); cf., Hitchen v. Phipps, 29 Vict. L.R. 422 (1903).

75 Pease v. Chavtor, 1 B.\&S. 620, 640, 122 Eng. Rep. 233, 240 (K.B. 1863); Singer v. Bogen, 147 Cal. App. 2d 515, 525, 305 P.2d 893, 900 (1957).

76 Justices of the Peace Act, 1327, 1 Edw. 3, c.16.

77 Justices of the Peace Act, 1361, $34 \mathrm{Edw} .3$, c. 1. See Maitland, Constitutional History of England 206-209, 232-233 (1913) for an historical vignette of the justice of the peace.

78 Everett v. Griffths, [1921] 1 A.C. 631, 666 (H.L.), per Visc. Finlay. This proposition is not entirely certain (see Visc. Cave at 679, Ld. Moulton at 696 and Everett v. Griffiths, [1920] 3 K.B. 163, 191 (C.A.) per Scrutton, L.J.) but seems to have respectably ancient authority. See Floyd v. Barker, 12 Co. Rep. 23, 77 Eng. Rep. 1305 (1607); Bassett v. Godschall, 3 Wils. K.B. 121, 95 Eng. Rep. 967 (1770). The difficulty stems from the dual nature of this office, and the desire to hold this official liable for malicious administrative acts but immune for all judicial acts.

79 For these facts, see Rogers v. Mulliner, 6 Wend. 597 (N.Y. Sup. Ct. 1831). 
the person against whom the warrant lies for so acting when it turns out that the person is a freeliolder.

This doctrine was too liarsh to be practical, so that at an early date in England, statutes were passed relieving such officers of responsibility for this type of error in their ministerial performance, so long as they act with probable cause, in good faith and within the general area of their jurisdiction. ${ }^{80}$ Similar statutes exist in Commonwealth jurisdictions. ${ }^{81}$ American jurisdictions on the other land appear to liave reached this common sense solution througl changing the coinmon law without benefit of statute, often by simply redefining as "judicial" that which in other courts is called "ministerial.".83

\section{E. Ministerial Court Officers}

A final category of officers who stand in an inproved position because of their connection with the judicial process are those sworn servants of the courts who perform ministerial duties upon order of the court. Sheriffs, bailiffs, and clerks of the court are historically in this category. They are joined today by officers with different nanies wlio are required by law to enforce the decrees of a court or a comparable body..$^{84}$

The privilege they have is to escape the consequences of a defect in the authority under which they act. In theory, such a non-judicial official acting under a defective authority, acts with no authority and is therefore subject to liability. So if the warrant by whicl the sheriff arrests has been iniproperly issued by the court, the sheriff, having no valid authority for his act, would be liable for false imprisoninent. Surprisingly, the coinmon law managed to avoid this pitfall by finding that the sheriff's sworn duty

80 See Justices Protection Act, $1848,11 \& 12$ Vict., c. $44, \S 2$ for this statute's present form. Evidently, "jurisdiction" as used here means merely that the matter must only be broadly within the "sphere" of matters dealt with by the justice. See Everett v. Griffiths, [1921] 1 A.C. 631, 666 (H.L.); Barton v. Bricknell, 13 Q.B. 393, 396, 116 Eng. Rep. 1313, 1314 (1850). The requirement of "good faith" makes this immunity significantly different from the ordinary "judicial immumity."

81 E.g., New South Wales, Justices Act, 2 Edw. 7, Act No. 27, \$§ 135-145; Nova Scotia, Justices' and Magistrates' Protection Act, 1954, R.S.N.S. c. 140; Ontario, Public Authorities Protection Act, 1950, R.S.O. c. 303, \$§ 1-10.

82 Tschuor v. Meck, 72 Ariz. 200, 232 P.2d 848 (1951); Yelton v. Becker, 248 S.W.2d 86 (Mo. App. 1952) ; Rogers v. Mulliner, 6 Wend. 597 (N.Y.Sup. Ct. 1831).

83 Aetna Ins. Co. v. Blumenthal, 129 Conn. 545, 29 A.2d 751 (1943); Allen v. Holbrook, 103 Utah 319, 135 P.2d 242, modified, 139 P.2d 233 (1943). This approach has the unfortunate effect of providing "all" instead of "nothing," i.e., the officer is immune for not only good faith acts but malicious ones as well.

84 Erskine v. Hohnbach, 81 U.S. (14 Wall.) 613, 616 (1871) (collector of taxes, U.S. tax assessment board); Allen v. Clark, 22 F. Supp. 898 (S.D. Cal. 1938) (U.S. Marsliall of federal court) ; Howard v. Gossett, 10 Q.B. 375, 411, 116 Eng. Rep. 139, 158 (Ex. Ch. 1845) (sergeantat-arms of House of Commons); Andrews v. Marris, 1 Q.B. 3, 113 Eng. Rep. 1030 (1841) (sergeant of small debt commissioners' court). 
to the court excused his injury to the individual. It was just not practical to put such an officer in the position that he needed a lawyer's advice before following the order of the court. So the rule has developed, that if the officer acts pursuant to judicial mandate which has no defects on its face and which is not obviously beyond the jurisdiction of the issuing court, ${ }^{85}$ he is protected from hability provided he executes the writ in a proper manner..$^{80}$

This protection does not extend to the case where the court officer, though through a bona fide mistake, acts beyond the authority of the writ. If he arrests the wrong person ${ }^{87}$ or seizes the wrong goods ${ }^{88}$ then, except in cases where estoppel arguments may lie, ${ }^{89}$ he will be personally liable, and neither the honesty nor the reasonableness of his error saves him. While creating hardship in a few cases ${ }^{90}$ a policy which keeps officials of whom the state asks nothing more than mere mechanical performance sharply conscious of the care with which they should perform and of the limits of their power, inures ultimately to the benefit of all the citizens, and in specific cases ensures that an injured individual who, on balancing the equities, will always be more innocent than the injurer-official, obtains compensation.

\section{Legislators}

Legislators are another small but privileged group, who have almost complete immunity at law for their words ${ }^{91}$ or deeds. There are three dis-

85 Marshalsea Case, 10 Co. Rep. 686, 77 Eng. Rep. 1027 (K.B. 1612) ; Parsons v. Loyd, 3 Wils. K.B. 341, 95 Eng. Rep. 1089 (K.B. 1772); Dews v. Riley, 11 C.B. 434, 138 Eng. Rep. 542 (C.P. 1851) ; Erskine v. Hohnbach, 81 U.S. (14 Wall.) 613, 616 (1871); Williams v. Franzoni, 217 F.2d 533 (2d Cir. 1954); Thompson v. Baker, 133 F. Supp. 247 (W.D. Ark. 1955); Savacool v. Boughton, 5 Wend. 170 (N.Y. Sup. Ct. 1830).

86 Countess of Rutland's Case, 6 Co. Rep. 52b, 77 Eng. Rep. 332 (Star Chamber 1606).

87 Kelly v. Lawrence, 3 H.\&C. 1, 159 Eng. Rep. 424 (Es. 1864); cf. Trull v. Howland, 64 Mass. (10 Cush.) 109 (1852); Bean v. Best, 93 N.W.2d 403 (S.D. 1958).

88 Harri v. Isaac, 111 Mont. 152, 107 P.2d 137 (19.10); Popkin v. Subm, 62 N.X.S. 480 (Sup. Ct. 1900) ; Balme v. Futton, 9 Bing 471, 131 Eng. Rep. 689 (Ex. Ch. 1833).

89 Zuehlke v. Stone, 148 Mich. 478, 111 N.W. 1065 (1907); Dunston v. Paterson, 2 C.B. (n.s.) 495, 140 Eng. Rep. 509 (C.P. 1857).

${ }^{90}$ In Glasspoole v. Young, 9 B.\&C. 696, 109 Eng. Rep. 259 (K.B. 1829), the sheriff, as he was then entitled to do, seized chattels of the plaintiff wife in partial fulfillment of an execution against the husband. Two years later, upon discovering her supposed marriage non-existent because of the appearance of a previous wife, the plaintiff wife was held entitled to recover in conversion against the sheriff for the seizure of her goods.

91 Liability of newspapers and other publishers for reporting such 'words' when they are defamatory is a topic beyond the scope of this paper. Briefly, however, publishers are generally exempt from liability for "fair reports" of legislative proceedings. In England and other Commonwealth countries, this privilege is by virtue of statute. E.g., Parliamentary Papers Act, 1840, 3 \& 4 Vict., c. 9 -England (cf. Stockdale v. Hansard, 9 Ad. \& E. 1, 112 Eng. Rep. 1112 (Q.B. 1839), for the common law position). In the United States, constitutional guarantces of freedom of the press (e.g., U.S. Const. amend. I) have been construed as giving rise to such a privilege. 
tinct elements to this privilege. ${ }^{92}$ The first, and by far the most important, is the freedom from being questioned in court for anything said in debates or proceedings of the legislature. Secondly, there is a privilege attached to certain acts which would amount to trespass to the person if done apart from the legislative scene. Finally there is the inability of courts to look behind legislation to the motives of the legislators as a basis of liability.

The absolute freedoin of speech of the legislator dates from the Bill of Rights of $1688 .^{93}$ Fresh from the experience of Stuart attempts, in conjunction with subservient courts, to stifle free debate in Parliament by treason and seditious libel prosecutions for words uttered there, ${ }^{94}$ the postRevolution Parliament called by Williain and Mary deemed protection against such acts essential to preserving the integrity of Parliament from the future pressures of the executives. Although the mind may balk at the thought that any of the ardent subversive hunters who populate AngloAmerican legislatures today could ever need such an immunity, it is undeniable history that the basic purpose of the privilege was to preserve legislators from criminal prosecution for sedition and the like at the hands of a tyrannous executive.

In modern times there have been occasions when the immunity has been required to protect legislators from penal consequences, ${ }^{95}$ but the more common use has been as an absolute bar to defamation actions. ${ }^{96}$ The

92 Immunity from arrest on civil process while the legislature is in session is a rather inconsequential fourth category. See Hiss v. Bartlett, 69 Mass. (3 Gray) 468 (1855); Goudy v. Duncombe, $1 \mathrm{Ex} .430$, 154 Eng. Rep. 183 (1847). Judges are accorded a similar privilege. See Adams v. Ackland, 7 U.C.Q.B. 211 (1850).

93 The Bill of Rights, 1689, 1 Wm. \& Mary, sess. 2, c. 2.

94 Case of Sir John Elliott, 3 State Tr. 293 (1629).

95 Oklahoma Bar Ass'n. v. Nix, 295 P.2d 286 (Okla. 1956) (suspension from state bar) (but the legislator is not protected when he repeats his statements later over television); Ex parte Wason, L.R. 4 Q.B. 573 (1869) (criminal conspiracy to deceive the House by false statements); King v. Creevey, 1 M.\&S. 273, 105 Eng. Rep. 102 (K.B. 1813) (criminal libel) (the privilege does not extend to reiteration of the same defematory remarks outside the House).

The mere fact that the words or act complained of occurred withm the physical confines of the legislature if not in legislative proceedings is no bar to either criminal or civil consequences. Coffin v. Coffin, 4 Mass. 1 (1808) (slanderous statement in members' gallery of legislature); Riviin v. Bilainkin, [1953] 1 Q.B. 485 (1952) (contempt of court in mailing certain letters).

90 Kelly v. Daro, 47 Cal. App. 2d 418, 118 P.2d 37 (1941); Van Riper v. Tumuity, 26 N.J. Misc. 37, 56 A.2d 611 (1948); Dillon v. Balfour, 20 L.R. Ir. 600 (Exch. 1887); Gipps v. McElhone, 2 N.S.W.L.R. 18 (1881). From the time of the Bill of Rights and thereafter, considerable doubt has existed as to the limits of judicial intervention in matters involving the privileges of legislatures. See Ashby v. White, 1 Bro. P.C. 62, 1 Eng. Rep. 417 (H.L. 1703). Pailles, C.B., in Dillon v. Balfour, supra, draws a distinction as to the scope of judicial surveillance between cases where the legislatures' privilege to arrest is in issue and where its privilege of free speech is questioned. But cf. The Sheriff of Middlesex Case, 11 Ad. \& E. 273, 113 Eng. Rep. 419 (Q.B. 1840).

In addition, the English parliament asserts the astonishing power of bringing persons who have had the teinerity to commence legal proceedings against Members for statements made or 
interpreting of this privilege so as to protect from civil consequences untruthful or mahcious legislators ${ }^{97}$ who defame unprotected citizens, has apparently never been seriously questioned. This exemption from civil liabihity is settled law, considered as basic to preserving a free legislature ${ }^{0 \theta}$ as the protection from criminal prosecution.

The second aspect of the legislative immunity has evolved from attempts of legislatures to punish citizens for contumacious conduct toward the legislature or its organs. ${ }^{98}$ The English Parliament in this respect has a considerably greater reach than the United States Congress or the various state and provincial legislatures. Because it is historically a court, ${ }^{100}$ Parliament can try and punish persons for breaches of its "privileges"101 no matter where they take place. ${ }^{102}$ Similarly, its officers, such as the Sergeant-atArms, are protected from defects in the process under which they act by the immunity which extends to court officers carrying out court orders. ${ }^{103}$

acts done in the course of parliamentary business, before the House for punishnient for "breach of privilege." For a discussion of the most recently contemplated exercise of this power, and its unpopular reception by the English press and public, see Thompson, Letlers to Ministers and Parliamentary Privilege, [1959] PuB. L. 10. See also the opinion of the Judicial Committeo of the Privy Council arising from the same case, Re Parliamentary Privilege Act, [1958] 2 All E.R. 329 (P.C.).

97 They are the only positive beneficiaries, as all others would be protected by the qualified privilege which the law of defamation attaches to occasions of public interest. In such a situation, express malice, as well as the ordinary ingredients of defamation, nust be proved. For a suggestion that "qualified privilege" is, in the opinion of many English legislators, all that is proper or necessary, see Thonipson, note 96 supra at 19. See also Bulletin of the International Commission of Jurists, No. 8, Dec. 1958, p. 38.

98 Tenney v. Brandhove, 341 U.S. 367 (1951), per Frankfurter, J., at 377, "Legislators are immune ... not for their private indulgence but for the public good. . . [T] [Tat it was not consonant with our scheme of government . . . to inquire into the nintives of legislators, has remained unquestioned. ..." See, however, Adam v. Ward, [1917] A.C. 309, 324 (H.L.), for a suggestion that this privilege could be "turned into an abominable instrunient of oppression."

${ }^{99}$ E.g., McGrain v. Daugherty, 273 U.S. 135 (1927) (arrest for failure to answer Senate committee subpoena); Marshall v. Gordon, 243 U.S. 521. (1917) (arrest of citizen for abusive letter to editor); Fielding v. Thonıas, [1896] A.C. 600 (arrest for walking out of hearing before legislature, after order to reniain) ; Burdett v. Abbot, 14 East 1, 104 Eng. Rep. 501 (K.B. 1811) (arrest of M.P. for publication libelling Parbament).

100 Parliament is the highest court of the Realm. See Kielley v. Carson, 4 Moo. P.C. 63, 89, 13 Eng. Rep. 225, 235 (1842), per Parke, B., "[T] he reasons why the Fiouse of Commons has this power, is not because it is a representative body with legislative functions, but by virtue of ancient usage and prescription ... [it is] a peculiar privilege [originating in] the High Court of Parliament, before its division. . . " And see Kilbourn v. Thompson, 103 U.S. 168, 183 (1880); Lake v. King, 1 Wms. Saund. 120, 85 Eng. Rep. 128 (K.B. 1667).

101 This is an euphemisn for "dignity."

102 Usually, this has involved abusive newspaper coinment. See Dill v. Murphy, 1 W.\&W. 342 (Vict. 1862) ; Burdett v. Abbot, 14 East 1, 104 Eng. Rep. 501 (K.B. 1811).

103 Howard v. Gossett, 10 Q.B. 375, 411, 116 Eng. Rep. 139, 158 (Ex. Ch. 1845). See text at note 84 supra. 
Other legislatures, including Congress, ${ }^{104}$ do not have this breadth of power. ${ }^{105}$ There is immunity where the tort complained of was inflicted as punishment for insult in the face of the legislature ${ }^{106}$ or where a witness has refused to appear before or answer the questions of a legislative committee pursuing a rightful legislative purpose. ${ }^{107}$ But where the legislature attempts to punish for disrespectful statements made out of its presence $e^{108}$ or commits for failure to appear before, or answer to legislative investigators whose reasons for requiring the individual's presence or testimony exceed the scope of their authorized purpose,$^{109}$ the official actually effecting the trespass will be personably liable. ${ }^{110}$ The legislators or Speaker who initiated the proceedings may be saved from liability because they acted through proceedings in the legislature in their capacity as legislators. ${ }^{111}$ From the scarcity of cases on the subject, ${ }^{112}$ it would appear that by definition, legislators cannot be attacked for their motives in enacting par-

104 Kilbourn v. Thompson, 103 U.S. 168 (1880); Marshall v. Gordon, 243 U.S. 521 (1917).

103 Kielley v. Carson, 4 Moo. P.C. 63, 13 Eng. Rep. 225 (1842). As to the powers of the federal Parliament of Australia, see Ex parte Fitzpatrick, 92 Commw. L.R. 157 (Austl. 1955). See, concerning Canada, Ward, Called to the Bar of the House of Commons, 35 CAN. B. REv. 529 (1957).

108 See Anderson v. Dunn, 19 U.S. (6 Wheat.) 204, 228 (1821). In Payson v. Hubert, 34 Can. Sup. Ct. 400 (1904), the Clerk of the Speaker of the Nova Scotia Assembly, acting on the Speaker's orders, was held privileged in ejecting and preventing re-entry of an unruly petitioner. There is an "imherent right of self-preservation" (Marshall v. Gordon, 243 U.S. 521 (1917)) in every legislative body "to protect itself from all impediments to the due course of its proceedings" (Kielley v. Carson, 4 Moo. P.C. 63, 13 Eng. Rep. 225 (1842)).

107 Tenney v. Brandhove, 341 U.S. 367 (1951) (Cahifornia); Burnham v. Morrissey, 80 Mass. (14 Gray) 226 (1859); Ex parte Dansereau, 19 L. Can. Jur. 210 (1875) (Quebec). See also Watkins v. United States, 354 U.S. 178 (1957); Sweezy v. New Hampshire, 354 U.S. 234 (1957), which indicate the possibility that where the plaintiff has been arrested for failure to answer questions of an investigative legislative committee, liability might fall on the arresting officer merely if the terms of reference of the investigation have not been clearly set out.

108 Marshall v. Gordon, 243 U.S. 521 (1917).

109 Kilbourn v. Thompson, 103 U.S. 168 (1880); McGrain v. Daugherty;, 273 U.S. 135 (1927). And see note 107 supra.

110 Since he acts under a defective, and thus non-existent, authority, and is not a "court officer." See Kilbourn v. Thompson, 103 U.S. 168 (1880); Kielley v. Carson, 4 Moo. P.C. 63, 13 Eng. Rep. 225 (1842).

111 The Kielley and Kilboum cases, note 110 sutpra, reach different conclusions on this point.

112 There are a number of cases involving municipal legislators which deny any personal liability for the effect of legislation, usually even where corrupt motives are alleged. See McHenry v. Sneer, 56 Iowa 649, 10 N.W. 234 (1881); Pawlowski v. Jenks, 115 Mich. 275, 73 N.W. 238 (1897); Jones v. Loving, 55 Miss. 109 (1877); East Nissouri v. Horsenan, 9 U.C.C.P. 189 (Ont. 1858). Since municipal legislative power is purely delegative, there would seem to be no theoretic objection to examining the bona fides of these legislators since there has been no delegation of power to act otherwise than in good faith. See Bricker v. Sims, 195 Tenn. 361, 259 S.W.2d 661 (1953). Sovereign legislatures operate under entirely different terms of reference. 
ticular legislation. ${ }^{113}$ Besides the practical problems involved, ${ }^{114}$ it would appear to be theoretically fallacious for the courts to interfere. Under the English Constitution, Parliament is perfectly entitled to pass a statute which frankly declares its malicious purpose, and the courts would be bound to give credence to it. While legislative power has more defined boundaries in the American system, the separation of powers doctrine would undoubtedly prevent any significant intermeddling of this nature. As Justice Johnson said in Fletcher v. Peck, ${ }^{115}$ "The acts of the supreme power must be considered pure ... because there is no power that can declare them otherwise."

\section{AdMinistrative OfFicers}

As we have seen, in general, Anglo-American law treats the members of that slightly esoteric group of officials, the head of state, the judiciary and legislators, with considerable solicitude. However, one would hardly call Dicey too harshly to account if these represent the only exceptions to his rule. What about the great mass of officials who keep society's gears meshed, those who operate the executive or administrative side of government?

The position of those officers whose duties are "ministerial" has been mentioned heretofore. They are the drones of modern society, faced theoretically with an almost intolerable legal dilemma. ${ }^{110}$ There is, however, another large group of officials, which includes the highest executive officers, whose duties, characterized by a right to make personal decisions based on thought and judgment, are usually terned "discretionary."

The distinction between the two groups is difficult to enunciate clearly, first, because many, if not most, administrative officials wear both hats, making it impossible to classify by particular offices, and second, because, as has been pointed out in a much quoted remark "it would be difficult to conceive of any official act, no matter how directly ministerial, that did

113 "[I]f the act be clothed with all the requisite forms of a law, a court . . . cannot sustain a suit . . . in consequence of the impure motives which influenced certain members of the legislature which passed the law. .. ." Fletcher v. Peck, 10 U.S. (6 Cranch) 87, 130 (1810), per Marshall, C.J. "I will not confine [immunity of legislators] to . . . specch, . . . but will extend it to the giving of a vote...." Coffin v. Coffin, 4 Mass. 1, 27 (1808). See also Tenney v. Brandhove, 341 U.S. 367 (1951).

114 For example, what is the influence of 1,10 or 100 corruptly motivated legislators on the passage of a particular statute?

11510 U.S. (6 Cranch) 87, 144 (1810).

110 "Theoretic" because, except for certain officials such as justices of the peace, sheriffs, bailiffs and policemen for whom special, more flexible rules apply, the dilemma rarely arises. The coinmonest case where the lower echelon public servant may be put in such a quandary is when ordered by his superior to do an act which turns out to be tortious. Even here he is normally protected by the facts (i) that the injured party will prefer to sue the superior; (ii) that if he is sued and held liable, he may be able to sue his superior for any damages he pays out [Prosser, TORTS 250 (2d ed. 1955)] ; (iii) that juries will understand and sympathize witlr his difficult position. [See Mason v. Wrightson, $205 \mathrm{Md}$. 481, $109 \mathrm{A.2d} 128$ (1954)]; and (iv) that government compensation in some form or other will be forthcoming. 
not admit of some discretion in the manner of its performance, even if it involved only the driving of a nail."117

Perhaps more helpful is to consider the problem from the point of view of what is the consequence to the official of particular conduct. In certain cases the official is held to the negligence standard of the ordinary citizen, and for all intentional torts which are not justified by a precisely followed authority. In others, the official is held only to a standard of honesty or bona fides. Inevitably, a no-man's land area in which any two given courts or judges may reach different conclusions as to the nature of any particular act will occur, ${ }^{118}$ since essentially the distinction is one of degree, but generally the conclusions reached from court to court are consistent.

Where an official exercises discretion in circumstances requiring an adjudicative decision, the making of an innocent mistake in judgment, as in the case of honest judicial error, is simply not a personally wrongful act, and quite properly the officer is not held personally liable. That somebody must suffer this officially inflicted injury without compensation merely demonstrates, once again, that a system of sovereign irresponsibility often forces unpalatable policy choices on the law. To ask a man to give his honest opinion and then impose liability on him for error, as we have seen with judges, is an impossible position. ${ }^{119}$ The only practical answer is non-liability for the officer, and let the injuries lie where they may.

But administrative discretion is not judicial discretion. ${ }^{120}$ So, untrammelled by the traditional ${ }^{121}$ and, probably, psychological ${ }^{122}$ reasons for giving absolute immunity to judicial officers, the law recognizes in the case of the administrative officers that it is no hardship to him to be held to honest performance of his duties, that is, to have his acts subjected to an examination by a judge or jury for mala fides with a presumption existing in favor of his good faith. ${ }^{123}$

117 Ham v. County of Los Angeles, 46 Cal. App. 148, 162, 189 Pac. 462, 468 (1920), per Sloane, J.

118 See Prosser, Torts 781-82 (2d ed. 1955).

110 Ferguson v. Kinnoull, 9 Cl. \& Fin. 251, 290, 8 Eng. Rep. 412, 426-27 (H.L. 1842), per Ld. Brougham, speaking of administrative officials. "[W]here they ... only have a discretion confided to thein, an erroneous exercise of that discretion, however plain the miscarriage may be, and however injurious ... they shall not answer for. This follows from the very nature of the thing; it is implied in the nature of judicial authority, and in the nature of discretion, where there is no such judicial authority. ..."

120 See Fry, L.J. in Royal Aquarium v. Parkinson, [1892] 1 Q.B. 431, 447, 448 (C.A.), note 64 supra.

121 See text at notes $27-48$ supra.

122 Arnold, The Symbols of Government, chs. 6, 8, 9 (1941).

123 Wilkes v. Dinsman, 48 U.S. (7 How.) 89, 130 (1849); Kendall v. Stokes, 44 U.S. (3 How.) 87, 788 (1845) ; Paoh v. Mason, 325 Ill. App. 197, 209, 59 N.E.2d 499, 504 (1945); Garden City v. Nation, 83 Kan. 237, 109 Pac. 772, 773 (1910); Memecke v. McFarland, 122 Mont. 515, 520, 206 P.2d 1012, 1014 (1949); State v. Swanson, 223 N.C. 442, 445, 27 S.E.2d 122, 123 (1943); State v. Farmers State Bank, 16 Tenn. 499, 39 S.W.2d 281, 282 (1931); 
Moreover, there are certain torts such as false imprisonment, battery and trespass to property, which officials sometimes commit in the exercise of their discretion, that are not protected by the bona fide intent of the officer in spite of the valid policy reasons which underlie the "good faith" rule. ${ }^{124}$ The law holds interference with these rights, except within strictly defined and comphed with limits, subject to an overbalancing policy.

Such inconsistencies demonstrate the uselessness of attempting to designate officials as discretionary or ministerial, and forcing rules to fit these categories. Because categorizing judges or legislators makes for easilyperhaps too easily -applied law, an attempt is made, aiming for simplicity but only compounding the perplexity, to do the same with officials who at any given moment may be performing administrative, adjudicative or legislative functions. The effort is futile.

The only general statement safe to make is that ordinarily officials get no favors froun the law, but that in certain circumstances which must be ascertained from case to case and which depend on the injury complained of, a lesser standard, but never less than honesty of motive, will constitute a valid defence. However, if this is true, that the maximum latitude allowed any administrative official in exercising his powers is to act in good faith, then Dicey's argument is upheld, for his statement was clearly intended only to emphasize that official arbitrariness under the Anglo-American law resulted in the personal liability of the official to his victim.

To illustrate briefly what these general statements signify in practical terms, take, for example, the case of the official who supervises the taxi business in a municipality. If he arrests a driver, without a warrant, for a suspected violation of regulations, he is held to reasonable grounds for so doing. If he unsuccessfully launches a prosecution of an alleged violation, he is liable for malicious prosecution only when lack of probable cause combined with a dishonest motive can be shown. ${ }^{125}$ If he seizes a mechan-

Everett v. Griffiths, [1921] 1 A.C. 631, 695 (H.L.) ; Tozer v. Child, 7 El. \& Bl. 377,119 Eng. Rep. 1286 (Ex. Ch. 1857) ; Harman v. Tappenden, I East 556, 102 Eng. Rep. 214 (K.B. 1801); McGillivary v. Kimber, 23 D.L.R. 189 (N.S. 1915), rev'd on other grounds, 52 Can. Sup. Ct. 146, 26 D.L.R. 164 (1915); Smith v. East Elloe Rural Dist. Council, [1956] 1 All. E.R. 855 (H.L.).

124 Rogers v. Rajendro Dutt, 13 Moo. P.C. 209, 15 Eng. Rep. 78 (1860); Musgrave v. Pulido, 5 App. Cas. 102 (P.C. 1879) ; Bates v. Clark, 95 U.S. 204 (1877) ; Ross Const. Co. v. Yearsley, 103 F.2d 589 (8th Cir. 1939); Crawford v. Eidman, 129 Fed. 992 (S.D.N.Y. 1902); Kozlowski v. Ferrara, 117 F. Supp. 650 (S.D.N.Y. 1954); In re Lewis, 83 Fed. 159 (N.D. Wash. 1897); Finnell v. Pitts, 222 Ala. 290, 132 So. 2 (1931); Odinetz v. Budds, 315 Mich. 512, 24 N.W.2d 193 (1946) ; Wiegand v. West, 73 Ore. 249, 144 Pac. 481 (1914); Konner v. State, 227 N.Y. 478, 125 N.E. 843 (1920); Raleigh v. Goshen, [1898] 1 Ch. 73 (1897); Hoye v. Bush, 1 Man. \& G. 775, 133 Eng. Rep. 545, (C.P. 1840) ; Folland v. Stevens, [1915] S. Austl. L.R. 25 ; Boyd \& Co. v. Smith, 4 Can. Ex. 116 (1894).

125 The same standards that apply to any person. 
ically defective car he must have met all formalities perfectly or else may have to answer in trespass or conversion. ${ }^{120}$ If he makes statements concerning members of the local taxi community which are defamatory, he is prima facie privileged, but not if it can be shown he spoke maliciously. ${ }^{127}$ In turning down a license application or settling a dispute between competing firms, he can err without incurring liability, but only so long as he errs in good faith.

Finally, to complete the general picture, the fact should be recollected than an official may have, as often an ordinary individual has, a perfect legal right to do some act which ultimately causes harm to another. In these circumstances the motivation of the person in so acting is entirely immaterial. ${ }^{128}$ Careless language in cases of this nature has caused difficulty in later cases of a much different type. ${ }^{120}$

\section{A. English and Commonwealth Views}

\section{In General}

The position of officials from cabinet ministers to church wardens in English and Commonwealth law conforms generally to the above discussed pattern. To scoff, as a recent American writer does, ${ }^{130}$ at the possibility of the Prime Minister being held personally liable for misuse of his discretionary power, is to rely on the exact terminology, Prime Minister, and to ignore the numerous cases in which high executive officers of comparable rank

126 It is in this situation that the diffcult and unsolved problem of "jurisdictional fact" most often enters to confound the administrative officer. If a court chooses to treat our official's power "to impound all mechanically defective cabs" as defining his jurisdiction, then upon a subsequent finding that the cab was not mechanically defective, the official will be liable in tort regardless of his good faith or dihgence in coming to his "mistaken" conclusions of fact. Cf. the famous case of Miller v. Horton, 152 Mass. 540, 26 N.E. 100 (1891).

Judicial officers are not placed in this untenable position. See text at note 73 supra. The problem is beyond the scope of this paper. For extensive treatment, see Davis, Administrative Officer's Tort Liability, 55 Mrce. L. REv. 201, 222-27 (1956); Jennings, Tort Liability of Admitistrative Officers, 21 MnNN. L. REv. 263, 276-97 (1936).

127 See Ross v. Lamport, [1955] Ont. 542 (C.A.), for a case with this fact situation where the "qualified privilege" attached to statements of public officers was lost by the utterer's makice.

128 Rogers v. Rajendro Dutt, 13 Moo. P.C. 209, 237, 15 Eng. Rep. 78, 89 (1860) ("[T]he foundation of every action of tort, apart from the question of malice, is an act wrongful, and which may be qualified legally as an injury. ..."); Kendall v. Stokes, 44 U.S. (3 How.) 87 , 788, 792 (1845) ("An act which the law sanctions cannot be considered as injurious to anyone. . . "); McHenry v. Sneer, 56 Iowa 649, 10 N.W. 234 (1881); Thibodaux v. Town of Thibodeaux, 46 La. Ann. 1528, 16 So. 450 (1894); Wilson v. Spencer, 91 Neb. 169, 135 N.W. 546 (1912); Wood v. Lyttelton, 25 T.L.R. 665 (C.A. 1909); Burr v. Smith, [1909] 2 K.B. 306 (C.A.) (in the case of the Inspector-General of Companies). Contra, Speyer v. School District No. 1, 82 Colo. 534, 261 Pac. 859 (1927), which suggests bad motive alone is enough.

120 Spalding v. Vilas, 161 U.S. 483 (1896). See text at note 202 infra.

130 Davis, Administrative Officer's Tort Liability, 55 MICH. L. REv. 201, 202 (1956). 
have been held subject to liability. ${ }^{131}$ Lords of the Admiralty, ${ }^{132}$ secretaries of state, ${ }^{133}$ secretaries of war, ${ }^{134}$ postmasters general, ${ }^{135}$ ministers of agriculture, ${ }^{136}$ of education ${ }^{137}$ or of highways, ${ }^{138}$ Governors of colonies ${ }^{130}$ and commissioners of income tax ${ }^{140}$ have all been held amenable to action across a complete spectrum of torts. Only a formal reservation exists as to the suability of these officials; that is, that an officer must be sued in his personal capacity and not in an official capacity. To sue an official as a named agent of the Crown is construed as an attempt to circumvent the immunity of the Crown, and the suit will be dismissed. ${ }^{141}$.

No master-servant relationship is held to exist between high and low officials of the same branch of government. Therefore a higher officer is not vicariously liable for the tortious conduct of a lower official in the same department. Rather the officers, the Postmaster General and the postman, say, are treated as fellow servants of the state. ${ }^{142}$ 'To found liability, there must be actual participation by the officer in the events creating the cause of action. Thus, only in the one case, where the inferior officer acts on the direct orders of a superior, will the superior officer be liable for any tortious acts of his subordinates. ${ }^{143}$ However, the inferior official always will be

131 See Roncarelli v. Duplessis, 4402 Montreal Supr. Ct., 2 May 1951, where the Premier of Quebec, M. Duplessis, was held liable for maliciously cancelling the plaintiff's restaurant liquor license. The Quebec Court of Appeal upheld the legal hability of the Prime Minister in such circumstances, but reversed because of insufficiency of the evidence. See [1956] Que. Off. L.R. 447 (C.A.). The Supreme Court of Canada restored the trial court verdict and increased the damages against the Premier to $\$ 33,000$. This decision, not because of the office involved, but because of the broad nature of liability asserted for arbitrary administrative acts and abuses or power not fitting into any recognized tort category, lonms as a landmark in Canadian civil rights cases and deserves (and no doubt will receive) extensive periodical examination. See 16 D.L.R.2d 689 (1959 S.C.C.).

132 Fraser v. Balfour, 87 L.J.K.B. 1116 (H.L. 1918) (wrongful dismissal); Raleigh v. Goschen, [1898] 1 Ch. 73 (1897) (trespass to land).

133 Liversidge v. Anderson, [1942) A.C. 206 (H.L. 1941) (false imprisoninent); Irwin v. Grey, 3 F.\&F. 635, 176 Eng. Rep. 290 (C.P. 1862) (negligence); Cobbett v. Grey, 4 Ex. 729, 154 Eng. Rep. 1409 (1849) (assault and false imprisonment).

134 Hutton v. Secretary of State for War, 43 T.L.R. 106 (Ch. 1926) (trespass to land).

135 Bainbridge v. Postmaster General, [1906] 1 K.B. 178 (C.A. 1905) (negligence).

136 Smith v. Christie, [1920] 3 West. Weekly R. 585 (Alta. App. Div.) (wrongful quarantine of cattle).

137 Hart v. Gumpach, L.R. 4 P.C. 439 (1872) (defamation).

138 Folland v. Stevens, [1915] So. Austl. L.R. 25 (nuisance).

130 See note 22 supra.

140 Jackson v. Magrath, 75 Commw. L.R. 293 (Austl. 1947) (defamation).

141 Raleigh v. Goschen, [1898] 1 Ch. 73, 79-80 (1897); Hutton v. Secretary of State for War, 43 T.L.R. 106 (Cl. 1926).

142 Bainbridge v. Postmaster General, [1906] 1 K.B. 178, 189 (C.A. 1905), per Collins, M.R., "[T] $]$ hese subordinate officers are officers of the Crown, and not in the relation of servants to their superior officers."

143 Sinith v. Christie, [1920] 3 West. Weekly R. 585 (Alta. App. Div.); Folland v. Stevens, [1915] So. Austl. L.R. 25; Raleigh v. Goschen, [1898] 1 Ch. 73, 77. 
liable as the actual perpetrator, acting by superior orders being considered as no excuse. ${ }^{144}$

Defamatory statements by public officials are particularly harmful to the individual defamed, since such statements almost invariably obtain widespread prominence. To allow an official special immunity from action for sucl statements would be to place a powerful weapon in the hands of the unscrupulous. On the other hand, there is a legitimate public interest that publicity shall be given by public officers to the problems besetting their area of jurisdiction. English law balances these extremes by holding the official liable only for those defamatory statements made for dishonest purposes, but otherwise allowing him the privilege of an honest mistake in the interest of public information. An injured person can thus obtain public vindication, while the official is protected from financial loss except where he has defamed maliciously. ${ }^{145}$

This rule applies, with one narrow exception, not only to statements publislied to the world at large, but also to those made in confidential intragovernmental communications. To leave a public officer helpless in the face of a vicious or untrue report by a superior would be highly unsatisfactory, especially in the modern civil service, where such reports would cling albatross-like to every officer throughout lis service. At the same time, as in every organization, public or private, an officer must often present to his superior his honest opinion of an inferior officer. So the same balance is struck, and liability ensues only when corrupt motive can be shown, ${ }^{146}$ althougl a somewhat different public interest-that of governmental efficiency-is at stake.

The one exception made to this rule is in the case of confidential communications between cabinet ministers or persons of higher rank. ${ }^{14 \tau}$ The much criticized case of Chatterton $v$. Secretary of State for India ${ }^{148}$ establislied a doctrine of absolute privilege for statements in communications of a much broader nature. ${ }^{149}$ Later cases have so narrowed the rule of this case

144 Johnstone v. Pedlar, [1921] 2 A.C. 262, 271; Winter v. Bancks, 65 J.P. 468 (C.A. 1901); Boyd \& Co. v. Smith, 4 Can. Exch. 116, 126 (1894); Mackay v. Abrahams, [1916] Vict. L.R. 681. 145 O'Connor v. Waldron, [1935] A.C. 76 (P.C. 1934); Adam v. Ward, [1917] A.C. 309; Royal Aquarium v. Parkinson, [1892] 1 Q.B. 431 (C.A.); Jackson v. Magrath, 75 Coinmw. L.R. 293 (Austl. 1947); Ross v. Lamport, [1955] Ont. 542 (C.A.).

146 Hart v. Gumpach, L.R. 4 P.C. 439 (1872) ; McCormick v. Cuthbert, 13 Austl. L.T. 137 (Vict. F.C. 1891) ; Gibbons v. Duffell, 47 Commw. L.R. 520 (Austl. 1932); Szalatnay-Stacho v. Fink, [1947] 1 K.B. 1 (1946).

147 For example, diplomats, kings.

148 [1895] 2 Q.B. 189 (C.A.).

140 Id. at 191. "[I]t is not competent to a civil Court to entertain a suit in respect of the action of an official ... in making ... a communication to another official in the course of his official duty. ..." The sole previous authority for this proposition is an off-hand paragraph in Fraser, Law of Libel and Slander 191 (5th ed. 1917). 
that it is in effect, now, so restricted as to be all but meaningless. ${ }^{160}$ The communication has to be at such a level as to constitute "an act of state" which in English law is usually connected with acts of the Government toward foreigners. ${ }^{151}$ The more acceptable explanation of this case, and one suggested in the judgment, is not that public policy requires the immunity of such officials, but that state security requires that communications passing at this level of government shall not be subject to discovery or exposure in court. ${ }^{152}$

At one time another exception to the rule was thought to exist with respect to communications between military officers concerning their subordinates. ${ }^{153}$ The justification for absolute privilege in this area was founded principally on the necessity of maintaining discipline. ${ }^{154}$ However, there have been such restrictions, criticisms and doubts cast on this exception, that it is probably no longer good law. ${ }^{165}$

\section{The Rules Governing Policemen}

The law relating to police officers and their rights to interfere with the citizen best illustrates the propensity of English law to hold the public officer to higli standards. This body of law represents a conscious attempt by the courts to keep under tight reins a public officer, potentially, having great

150 Gibbons v. Duffell, 47 Commw. L.R. 520, 530 (H.C.Austl. 1932); Jackson v. Magrath, 75 Commw. L.R. 293, 306 (H.C. Austl. 1947); Szalatnay-Stacho v. Fink, [1947] 1 K.B. 1 (1946). The latter case involved a communication from a high placed official (Judge Advocate General) of the Czechoslovak government-in-exile to the Presilient of the same government. At trial, Henn Collins, J., held the Chatterton privilege did not exist in "communications passing at a lower level than those between Ministers."

The House of Lords has never adopted the Chatterton doctrine even in its restricted form. It was apparently felt to be futile to argue this privilege to the Lords in Adam v. Ward, [1917] A. C. 309 (H.L.), although the communication was between such eminent officials as the Secretary to the Army Council and a Major-General.

151 See Johnstone v. Pedlar, [1921] 2 A.C. 262. The two cases where this absolute privilege has been held by English courts to attach to official communications, Chatterton v. Secretary of State for India, [1895] 2 Q.B. 189 (C.A.) and M. Isaacs \& Sons v. Cook, [1925] 2 K.B. 391, have both contained elements involving foreign territorics or governments.

152 Chatterton v. Secretary of State for India, [1895] 2 Q.B. 189, 193, 195 (C.A.). Seo Anderson v. Hamilton, 2 B.\&B. 156 n.(b), 129 Eng. Rep. 917 (H.L. 1816); Home v. Bentinck, 2 B.\&B. 130, 129 Eng. Rep. 907 (Ex. Ch. 1820); McCarthy v. City of Regina, 60 D.L.R. 205 (Sask. K.B. 1921).

153 Dawkins v. Lord Paulet, L.R. 5 Q.B. 94 (1869).

154 Id. at 119. But of. Cockburn, C.J., at 108-109.

155 In Fraser v. Balfour, 87 L.J.K.B. 1116, 1118 (H.L. 1918), Ld. Finlay pointedly noted that "the question is ... still open ... in this House". See Porrock, Torts 198 (15th ed. 1951) ("[not] conclusive); Bower, The Law of Actionable Defasuition 87 n.(j) (2d ed. 1923) ("an anomalous case ... undoubtedly wrong"); ODGERS, LIDEI AND SLANDER 246 (5th ed. 1911) ; Wright v. Cantrell, 44 N.S.W. St. 45 (1943) (not applicable where military commander defames civilian employee of military establishment) ; Gibbons v. Duffell, 47 Commw. L.R. 520 (Austl. 1932); Szalatnay-Stacho v. Fink, [1947] 1 K.B. 1, 10 (C.A. 1946) ; Heddon v. Evans, 35 T.L.R. 642 (K.B. 1919). 
powers to derogate from the freedom of the citizen. The trick is to do so without stifling his ability to enforce the law, and prevent and destroy crime in the community.

The principal tort problem facing police officers is, when is an arrest legal? Every arrest is prima facie actionable, the arrestor being required to justify. Therefore the safest position, tort-wise, for a police officer is to arrest by warrant. Then unless he knowingly arrests some person other than that named by the warrant ${ }^{256}$ he is protected even though the warrant is defective, unless, of course, the defect was obvious on its face, or the lack of jurisdiction of the issuing authority is glaringly apparent. ${ }^{157} \mathrm{He}$ is, thus, in exactly the position of a sheriff effecting the order of a court. ${ }^{158}$

This was not true at ancient common law, as the constable was not considered to have a close enough connection to the courts to claim such immunities. ${ }^{159}$ But to require the constable as his sworn duty to enforce criminal warrants and then penalize him if they contained hidden defects was patently so absurd that as early as 1750 statutory relief was provided. ${ }^{160}$

Obviously, numerous occasions arise on which police officers must arrest without first obtaining a warrant. To place narrow limits on the right of officers to make such arrests would all but destroy the efficiency of the police. However, a system of law which holds that "the liberty of the subject and the convenience of the police or any other executive authority are not to be weighed in the scales against each other"161 is reluctant to go the whole way and make honesty of belief the criterion of justification. So a compromise is reached, and a reasonable belief is required of the officer, ${ }^{162}$

At common law, a peace officer may arrest without warrant when he has reason to believe that the arrested person is committing or about to commit

158 Hoye v. Bush, 1 Man. \& G. 775, 133 Eng. Rep. 545 (C.P. 1840).

157 Horsfield v. Brown, [1932] 1 K.B. 355 (1931). See Report of the Royal Commission on a draft Crimimal Code (United Kingdom 1880). "[I]f the order or warrant was one which the ... magistrate could under any circumstances lawfully issue, ... the ... officer is not bound to inquire ... and is not to blame for acting. . . "; Sleeth v. Hurlbert, 25 Can. Sup. Ct. 620 (1896) ; Hill v. Warner, 7 Mar. Prov. 37 (N.S. 1933).

158 See text at notes 85-90 supra.

150 For the position at common law of an officer arresting by means of a defective warrant, see Money v. Leach, 1 W. Bl. 555, 96 Eng. Rep. 320 (K.B. 1765). This case stands also for the proposition that general warrants of arrest (e.g., "arrest all printers") are illegal.

100 Constables Protection Act, 1751, 24 Geo. $\Pi$, c. 44. This protection is applicable to defective search warrants as well as warrants of arrest. See Sleeth v. Hurlbert, $25 \mathrm{Can}$. Sup. Ct. 620 (1896). Comparable statutes exist in the various Commonwealth jurisdictions.

161 Per Ld. Simonds in Christie v. Leachinsky, [1947] A.C. 573, 595 (H.L. 1946). So, it is not too surprising to find that forced fingerprinting prior to committal for trial is a trespass to the person, or that handcuffing is only rarely permissable. See Dumbell v. Roberts, [1944] 1 All E.R. 326 (C.A.); Osborn v. Veitch, 1 F.\&F. 317, 175 Eng. Rep. 744 (1858).

162 Id. at 596-97 where Ld. du Parcq offers an excellent historical sketch of the gradual evolution of the "reasonable suspicion" rule-_"one of the few privileges [the police] enjoy at common law." 
a treason, felony or breach of the peace in his presence, ${ }^{103}$ or that a treason or felony has been committed, though out of his presence, within the jurisdiction by the person arrested. ${ }^{104}$ The common law position has been augmented in many jurisdictions so that reasonable belief ${ }^{165}$ that a misdemeanor is being committed, is now a justification of arrest. ${ }^{106}$

An arrest when made, whether with or without a warrant must be made in a prescribed manner ${ }^{167}$ or as close thereto as the circumstances permit. ${ }^{168}$ The officer should identify himself, and identify to the person arrested the act for which he is arrested, unless this is perfectly obvious from the situation. ${ }^{169}$ Thus, the courts attempt to prevent any police practice of arresting first, and manufacturing a reasonable ground later. Failure to explain the arrest, or stating one crime while suspecting a different one, results in making an otherwise valid arrest actionable. ${ }^{170}$

Suspected persons cannot be arrested for purposes of questioning

103 Price v. Seeley, 10 Cl. \& Fm. 28, 8 Eng. Rep. 651 (H.L. 1843); Cook v. Nethercote, 6 Car. \& P. 741, 172 Eng. Rep. 1443 (C.P. 1835) ; Handcock v. Baker, 2 B.\&P. 260, 126 Eng. Rep. 1270 (C.P. 1800); Cottrell v. Hueston, 7 U.C.C.P. 277 (1858).

164 Walters v. W.H. Smith \& Son, Ltd., [1914] 1 K.B. 595 (1913); Beckwith v. Philby, 6 B.\&C. 635, 108 Eng. Rep. 585 (K.B. 1827); Samuel v. Payne, 1 Doug. 359, 99 Eng. Rep. 230 (K.B. 1780); McArdle v. Egan, 150 L.T.R. 412 (C.A. 1934). Knowledge that a warrant has becn issued for the arrest of a particular person for a felony is a sufficient ground of reasonable suspicion that a felony has been committed by that person. Creagh v. Gamble, 24 L.R. Ir. 458 (Ex. 1888). Reasonable suspicion of a felony having been committed abroad is not sufficient. Diamond v. Minter, [1941] 1 K.B. 656. But in a sister province of Canada, it is sufficient. Queen v. Cloutier, 2 Can. Crim. Cas. Ann. 43 (Man. Q.B. 1898).

${ }^{165}$ As to the issue of who decides-judge or jury-whether the circumstances amount to reasonable grounds so as to justify an arrest without warrant, there is a split of authority. Several English decisions, in justifying reversal of jury verdicts, have held that this question is for the judge only. Panton v. Williams, 2 Q.B. 169, 114 Eng. Rep. 66 (Ex. Ch. 1841); Lister v. Perryman, L.R. 4 H.L. 521 (1870); McArdle v. Egan, 150 L.T.R. 412 (C.A. 1934). Contrary views have been expressed as to the law of Scotland, Canada and Australia. See respectively, Ld. Collonssay at 538 in Lister v. Perryman, supra; Cottrell v. Hueston, 7 U.C.C.P. 277 (Ont. 1858); Bales v. Parmeter, 52 N.S.W. Weekley N. 41 (1935).

166 Nolan v. Clifford, 1 Commw. L.R. 429 (Austl. 1904); Whitworth v. Dunlop, [1934] 1 West. Weekly R. 604 (B.C.C.A.).

167Countess of Rutland's Case, 6 Co. Rep. 52b, 77 Eng. Rep. 332 (Star Chamber 1606); Hooper v. Lane, 6 H.L. Cas. 443, 550 (1856); Horsfield v. Brown, [1932] 1 K.B. 355 (1931); R. v. Curvan, 1 Mood. 132, 168 Eng. Rep. 1213 (1826); Little v. Commonwealth, 53 Argus L.R. 483, 484 (H.C. 1947); Koechlin v. Waugh, [1957] Ont. Weekly N. 245 (C.A.).

168 Mackalley's Case, 9 Co. Rep. 65b, 77 Eng. Rep. 828 (K.B. 1611); Tims v. John Lewig \& Co. Ltd., [1951] 2 K.B. 459, 467, (per Goddard, L.C.J., "[I]f an officer is arresting a deaf person, he [does not have] to possess himself of an ear trumpet ... or shout at the top of his voice. ...").

169 [T] here is no need ... to explain the reason of arrest, if the arrested man is cauglit red-handed and the crime is patent to high Heaven. . . " Per Ld. Simonds in Christie v. Leachinsky, [1947] A.C. 573, 593 (H.L.).

170 Ibid; Dumbell v. Roberts, [1944] 1 All E.R. 326 (C.A.); Koechlin v. Waugh, [1957] Ont. Weekly N. 245, 247 (C.A.); Garthus v. Van Caeseele, 27 West. Weekly R. (n.s.) 431 (B.C. Sup. Ct. 1959). Contra, Broughton v. Williams, 28 Tasm. L.R. I (1932). This requirement signifies that the officer must make known the "act" for which the accused is arrested, not the exact legal "charge." 
only. ${ }^{171}$ The arresting officer has a duty to get a validly arrested person before a magistrate "without unreasonable delay, by the most reasonably direct route." 172 Failure to do so will result in liability for false imprisonment for the extra period involved. ${ }^{173}$ One benefit to the police officer in so doing is that, the moment a justice commits the accused, the arrest without warrant where no reasonable ground exists, ceases to be an illegal imprisonment for which the officer can incur further liability. ${ }^{174}$

Incidental to a valid arrest is the common law right of an arresting officer to search the person and immediate surroundings of the arrested individual. Any evidence of crime that such a search unearths can be seized. ${ }^{175}$ This right of search, however, is only exercisable where the circumstances of the arrest indicate its reasonableness, ${ }^{176}$ and is, of course, entirely dependent on the legality of the arrest to which it is ancillary. ${ }^{177}$

The right of entry on private property by peace officers, apart from execution of distress and search warrants, is confined to attempts to effect an arrest by warrant, to arrest a felon, to prevent the occurrence of a felony, or to occasions where the officer is in fresh pursuit of a fleeing criminal. ${ }^{178}$ Otherwise, entry lawfully can be had only by permission of the possessor who may withdraw this license, and sue in trespass, if the officer then refuses to leave. ${ }^{179}$

Grants of search warrants to peace officers are restricted to jealously guarded limits. A justice or magistrate may issue such a warrant only upon a sworn information that a crime has been committed by a named person, and that there is just cause to believe that specified goods or documents involved in the crime can be found within certain premises. Such stringent conditions, backed up by the possibility of civil action for abuses, discourage fishing expeditions, based on mere suspicion, and made in hopes of un-

171 Bales v. Parmeter, 52 N.S.W. Weekly N. 41 (1935).

$172 \operatorname{Re}$ Leary, 62 N.S.W. Weekly N. 146, 147 (1945) per Maxwell, J.

173 Frey v. Fedoruk, [1949] 2 West. Weekly R. 604 (B.C.C.A.) ; Clarke v. Bailey, 33 N.S.W. St. 303 (1933). A reasonably "direct route" is sufficient. The question is whether, in all the circumstances, the accused has been brought before a justice in a reasonably short time. See John Lewis \& Co. v. Tims, [1952] A.C. 676.

174 Christie v. Leachinsky, [1947] A.C. 573, 583 (H.L.) ; Dianond v. Minter, [1941] 1 All E.R. 390,397 (K.B.).

175 Elias v. Pasmore, [1934] 2 K.B. 164; Barnett v. Campbell, 21 N.Z.L.R. 484 (C.A. 1902) ; Field v. Sullivan, [1923] Vict. L.R. 70 (F.C. 1922).

176 Dillon v. O'Brien, 16 Cox Crim. Cas. 245 (Ex. 1887) (Ire.) ; Clarke v. Bailey, 33 N.S.W. St. 303, 310 (1933). Safety of the arresting officer, or preservation of important evidence, are reasonable circumstances.

177 Clarke v. Bailey, 33 N.S.W. St. 303 (1933).

178 Burdett v. Abbot, 14 East 1, 104 Eng. Rep. 501 (K.B. 1811) (by warrant); Smith v. Sliriey, 3 C.B. 142, 136 Eng. Rep. 58 (C.P. 1846) (felony) ; Handcock v. Baker, 2 B.\&P. 260, 126 Eng. Rep. 1270 (C.P. 1800) (felony); R. v. Marsden, L.R. 1 C.C.R. 131 (1868) (fresh pursuit).

179 Davis v. Lisle, [1936] 2 K.B. 434; Mackay v. Abrahams, [1916] Vict. L.R. 681. 
covering something incriminating. ${ }^{180}$ Additionally, the scope of such warrants will be construed rather strictly against the searcher. ${ }^{181}$

Whenever possible, police officers endeavour to avoid initiating criminal proceedings, encouraging non-official complainants to lay such charges. However, when an officer is involved in initiating proceedings, he is as amenable as any private person to actions for malicious prosecution. His position is identical with the well protected one of any prosecutor, that is, both lack of probable cause and actual malice must be proved against him before liability ensues. ${ }^{182}$

Finally, it should be noted that a peace officer in his ordinary functions is not considered a servant or agent of the municipality or police commission which pays his salary. Historically, the peace officer performs his office as a servant of the Crown ${ }^{183}$ sworn "to preserving the peace ... preventing felonies and misdemeanours and to apprehending offenders." 184 The conception is upheld on the theory that it enables the police officer to do his duty as he sees it without excessive local interference. ${ }^{185}$ An unfortunate effect of this rather contrived doctrine is that there is no master other than the immune state, to be held vicariously liable for a policeman's torts. ${ }^{180}$ Once again, the injured plaintiff is left holding the often empty bag of personal responsibility of the peace officer. However, this is tempered by the

180 Wilkes v. Wood, 19 State Tr. 1154 (1763), and Entick v. Carrington, 19 State Tr. 1029, 1067 (1765), decided the illegality of general search warrants. The warrant in the latter case was granted to search certain premises because of a "suspicion" seditious literature was hidden there. "If this point slould be determined in favour of the [legality of such a warrant] the secret cabinets and bureaux of every subject in this kingdom will be thrown open to the search and inspection of ... the Secretary of State whenever lie thinks fit to . . . suspect. . .." Per Ld. Camden, at 1063.

181 R. v. Paint, 36 D.L.R. 717 (N.S. 1917) ; Gordon v. Chief Commissioner of Metropolitan Police, [1910] 2 K.B. 1080 (C.A.); Crozier v. Cundey, 6 B.\&C. 232, 108 Eng. Rep. 449 (K.B. 1827).

182 Manning v. Nickerson, [1928] Can. Sup. Ct. 91 (1927); Humphrey v. Archibald, 21 Ont. 553 (Ch. 1892) (warrant of arrest); Grady v. Devitt, [1928] 1 West. Weekly R. 924 (B.C.) (search warrant); Hawker v. Hillsburgh, [1942] 2 West. Weekly 488 (Sask. K.B.).

183 Fisher v. Oldhain Corp., [1930] 2 K.B. 364; McCleave v. City of Moncton, 32 Can. Snp. 106 (1902); Enever v. The King, 3 Cominw. L.R. 969 (Austl. 1906) ; British South Africa Co. v. Crickmore, [1921] So. Afr. L.R. 107 (App. Div.).

184 This was the oath sworn, pursuant to the Municipal Corporations Act, 1882, 45 \& 46 Vict., c. 50, $\$ 191(2)$, by the police constable in Fisher v. Oldham Corp., note 183 supra. It is, as McCardie, J., suggests, obviously directed at upholding the Queen's laws, not mercly the local ordinances. This oath is "the characteristic unark of the conversion of the local ... officer into [an] ... officer of the Crown." See Simpson, The Ofice of Constable, 10 Eva. HIst. Rev. 625 (1895).

185 See Fisher v. Oldham Corp., note 183 supra at 377-78.

186 This is so under the Crown Proceedings Act, 1947, 10 \& 11 Geo. 6, c. 44 and comparable Commonwealth statutes. See StreEt, Governarentac Liabimity 33-34 (1953); Wade, English Governmental Tort Liability, 29 N.Y.U.L. Rev. 1416, 1423 (1954). And see, Enever v. The King, 3 Commw. L.R. 969 (Austl. 1906). 
common existence, in contemplation of such eventualities, of insurance and police "emergency" funds.

\section{B. American Views}

\section{In General}

Does the American picture conform with the general hypothesis that, at the very least, an administrative officer must act in good faith or suffer the consequences? For the most part, the answer appears to be yes. But there is a disturbing recent trend, almost entirely in the federal courts, which presents a sharp cleavage from the formulated rule and the Commonwealth cases. These cases hold that there is a group of officials-and the indications are that this is a frighteningly large group_- ${ }^{187}$ who with respect to certain conduct are bound to no standard whatsoever other than that of acting roughly within their area of jurisdiction. That is, even the mininal requirement of honesty of motive is not demanded of these officers in certain cases. The remainder of this paper will be directed principally to examining the source, validity, scope and extent of this doctrine.

First of all, however, it should be einphasized that this line of cases, taking them even at their broadest sweep, is a limited exception to a general acceptance by American courts of rules of official tort liability similar to those of the Commonwealth jurisdictions. The general framework is identical. Officers are sued in their personal capacity. ${ }^{188}$ Respondeat superior does not apply between ligh and low officers; rather they are fellow servants of the state. ${ }^{189}$ Superior orders are no excuse. ${ }^{190}$ Policemen are servants of the state, not the corporation for whom they work. ${ }^{191}$ The rules as to arrest and search, both with and without warrants, are substantially the

187 See text at notes 216-22 infra.

188 Armacost v. Conservation Commission, 126 F. Supp. 414 (S.D.W.Va. 1954) ; Moon v. Hines, 205 Atl. 355, 87 So. 603 (1921) ; Holman v. County of Santa Cruz, 91 Cal. App. 2d 502, 205 P.2d 767 (1949); Reed v. Molony, 38 Cal. App. 2d 405, 101 P.2d 175 (1940). American courts are not as finicky as English courts (see note 141 supra) over this formality, and will consider the allegations as a whole and not just look to the title.

189 Robertson v. Sichel, 127 U.S. 507 (1888) ; Jones v. Kennedy, 121 F.2d (D.C. Cir.) cert. den., 314 U.S. 665 (1941) ; Marshall v. County of Los Angeles, 131 Cal. App. 2d 812, 281 P.2d 544 (1955); Leger v. Kelly, 19 Conn. Supp. 167, 110 A.2d 635 (Super. Ct. 1954); Dowler v. Johnson, 225 N.Y. 39, 121 N.E. 487 (1918); Giroux v. Murphy, 147 A.2d 465 (R.I.1959); Pavish v. Meyers, 129 Wash. 605, 225 Pac. 633 (1924).

100 Bates v. Clark, 95 U.S. 204 (1877) ; Shelton v. Barry, 328 Ill. App. 497, 66 N.E.2d 697 (1946) ; Mason v. Wrightson, 205 Md. 481, 109 A.2d 128 (1954); Collins v. Cody, 95 N.J.L. 65, 113 Atl. 709 (1920); Wiegand v. West, 73 Ore. 249, 144 Pac. 481 (1914).

101 Kansas City v. Lemen, 57 Fed. 905 (8th Cir. 1893) ; Buttrick v. City of Lowell, 83 Mass. (1 Allen) 172 (1861); Aldrich v. City of Youngstown, 106 Ohio St. 342, 140 N.E. 164 (1922) ; Bricker v. Sims, 195 Tenn. 361, 259 S.W.2d 661 (1953). But see, under special statutes, Gaca v. City of Chicago, 411 Ill. 146, 103 N.E.2d 617 (1952); McCrink v. City of New York, 296 N.Y. 99, 71 N.E.2d 419. 
same. ${ }^{192}$ Moreover, all courts, federal and state, seem to agree with the strict approach concerning liability of officers for torts such as false imprisonment, battery, trespass to property and negligence. ${ }^{103}$

Since, even in these days of centralization, there are, excluding the military, nuany more state officials roaming the American countryside than federal ones, ${ }^{104}$ it is particularly important that nost state courts have not accepted the exceptional doctrine under discussion, ${ }^{105}$ apart from the case of one peculiar, and easily distinguishable, official. ${ }^{108}$ Thus, it seems fair to say that overall the administrative official in the United States is held to the same standards as his counterpart in other common law countries. However, the exception which appears to apply to torts such as defamation,

192 Wolf v. Colorado, 338 U.S. 25, 30 n.1 (1949) (search as incident of arrest); Bell v. Hood, 327 U.S. 673 (1946) (search without warrant, delay, F.B.I., Civ. Rts. Act) ; Agnello v. United States, 269 U.S. 20 (1925) (unlawful search of house); Davis v. Turner, 197 F.2d 847 (5th Cir. 1952) (arrest without warrant, delay, Civ. Rts. Act); Kozlowski v. Ferrara, 117 F. Supp. 650 (S.D.N.Y. 1954) (arrest without warrant) ; Moran v. Lumberman's Mut. Cas. Co., 92 F. Supp. 267 (E.D. Mich. 1950) (force as incident to arrest); Bull v. Armstrong, 254 Ala. 390, 48 So. 2d 467 (1950) (search by warrant) (warrants in blank defective on face); Miller v. Glass, 44 Cal. 2d 359, 282 P.2d 501 (1955) (arrest without warrant for misdemeanor); Hughes v. Oreb, $36 \mathrm{Cal} .2 \mathrm{~d} 854,228 \mathrm{P} .2 \mathrm{~d} 550$ (1951) (arrest without warrant, must inform accused of cause); Barrier v. Alexander, $100 \mathrm{Cal}$. App. 2d 497, 224 P.2d 436 (1950) (arrest by warrant); Hefler v. Hunt, 120 Mo. 10, 112 Atl. 675 (1921) (arrest with warrant, delay in taking to magistrate); Mason v. Wrightson, 205 Md. 481, 109 A.2d 128 (1954) (search as incident of arrest); Hammitt v. Straley, 338 Mich. 587, 61 N.W.2d 641 (1953) (arrest without warrant, judge may direct finding of reasonableness); Odinetz v. Budds, 315 Mich. 512, 24 N.W.2d 193 (1946) (arrest without warrant, reasonableness primarily a jury question); Berger v. Village of Seneca Falls, 151 N.Y.S.2d 133 (Sup. Ct. 1956) (committal by court order); Nastasi v. State, 275 App. Div. 524, 90 N.Y.S.2d 377 (1949) (arrest by warrant); Jobnson v. Reddy, 163 Ohio St. 347, 126 N.E.2d 911 (1955) (arrest without warrant at request of police in anotber state who have warrant, must take before magistrate with all practicable speed) ; Maxey v. Gather, 94 Ohio App. 115, 114 N.E.2d 607 (1952) (arrest by warrant); Bricker v. Sims, 195 Tenn. 361, 295 S.W.2d 661 (1953) (arrest without warrant, unconstitutional statute); Mitchell v. Hughes, 104 Wash. 231, 176 Pac. 26 (1918) (arrest without warrant, right to resist unidentified officers).

193 Belknap v. Schild, 161 U.S. 10, 23 (1896) (patent infruigement); Geach v. Moynahan, 207 F.2d 714 (7th Cir. 1953) (battery, Civil Rts. Act); DeBonis v. United States, 103 F. Supp. 123 (W.D. Pa. 1952) (trespass to property); Vietzke v. Austin Co., 54 F. Supp. 265 (E.D. Wash. 1944) (conversion) ; Towle v. Ross, 32 F. Supp. 125 (D.C. Ore. 1940) (copyright infringement); Elmore v. Fields, 153 Ala. 345, 45 So. 66 (1907) (trespass to land); Fernelius v. Peirce, 22 Cal. 2d 226, 138 P.2d 12 (1943) (negligence). And see also, cases cited in notes 124 and 192 supra; Leger v. Kelly, 19 Conn. Supp. 167, 110 A.2d 635 (1954) (negligence); Erickson v. Fitzgerald, 342 Ill. App. 223, 96 N.E.2d 382 (1950); Whitt v. Reel, 239 S.W.2d 489 (Ky. 1951) (negligence); Streipe v. Liberty Mut. Ins. Co., 243 Ky. 15, 47 S.W.2d 1004 (1932) (infliction of mental distress); Trum v. Town of Paxton, 329 Mass. 434, 109 N.E.2d 116 (1952) (negligence); Konner v. State, 227 N.Y. 478, 125 N.E. 843 (1920) (trespass to land) ; Hutchison v. Mitterling, 2 Pa. D.\&C.2d 793 (Dist. Ct. 1955) (trespass to chattels) ; Hjorth v. Whittenburg, 121 Utah 324, 241 P.2d 907 (1952) (injury to adjacent property on improving a highway); Mitcheli v. Hughes, 104 Wash. 231, 176 Pac. 26 (1918) (battery).

194 See statistics note 1 supra. The ratio is a little more than two to one.

105 See note 246 infra and accompanying text.

108 The public prosecutor. See text at notes $239-45,261-64$ infra. 
malicious prosecution, wrongful dismissal and the like, is a significant gap in the citizen's protection against the completely arbitrary conduct of the public official.

\section{The Federal Immunity Doctrine}

In essence, the contention is that an official has an immunity from liability for torts of this nature, where the occasion on whicl he acted "would have justified the act, if he had been using his power for [proper] purposes." 107 As a condition, this is nothing perceptibly more than a requirement of general jurisdiction. Thus seemingly if an official's job involves giving public statements concerning a particular area of government, he may deliberately slander someone in this field to his heart's content; ${ }^{198}$ or if he must make reports on his subordinates, he may spew forth libels to satisfy a personal desire for retribution; ${ }^{199}$ or if his duties include policing a building ordinance, he may persecute as well as prosecute; ${ }^{200}$ and all these base objectives he can admit to in court and for none will he face civil liability because the public statement, the report, the prosecution, would have been "justified" if he had been using his power "for any of the purposes on whose account it was vested in him." 201

\section{a.Spalding $v$.Vilas}

The keystone of this whole doctrine is the 1895 Supreme Court decision in Spalding v. Vilas. ${ }^{202}$ What was involved was a dispute between the Postmaster General, Vilas, ${ }^{203}$ and an angry lawyer-lobbyist, Spalding. Spalding, for several years, had been acting on behalf of some 4,000 local postmasters in an effort to obtain legislation from Congress for certain retroactive salary adjustments in their favor. Over the opposition of Vilas, Congress eventually passed this legislation, but attached to it the rider that payments were to be made only to the postmasters directly, upon their filing claims, and that any powers of attorney made without certain formalities or before passage of the act, were null and void. Spalding submitted numerous claims together with several thousand invalid powers of attorney. Vilas responded by sending the government checks directly to the postmasters, accompanied by a letter which cited the statutory provisions and pointed out that

197 Gregoir v. Biddle, 177 F.2d 579, 581 (2d Cir. 1949) (per Learned Hand, J.) ; cert. den., 339 U.S. 949 (1950).

198 Glass v. Ickes, 117 F.2d 273 (D.C. Cir. 1940), cert. den., 311 U.S. 718 (1941).

199 De Arnaud v. Ainsworth, 24 App. D.C. 167, 5 L.R.A. (n.s.) 163 (1904).

200 White v. Brinkman, 23 Cal. App. 2d 307, 73 P.2d 254 (1937).

201 Gregoire v. Biddle, 177 F.2d 579, 581 (2d Cir. 1949), cert. den., 339 U.S. 718 (1950). 202161 U.S. 483 (1896).

203 Postmaster General in the Cleveland administration, he was at the time this case was decided, Democratic Senator from Wisconsin. See Spalding v. Mason, 161 U.S. 375 (1898), for an interesting sidelight on this case, and for figures indicating the cost to Spalding of Vilas' actions. 
Congress, intending that the money should go to them directly, had accordingly set up a procedure whereby no attorney's services were necessary in presenting claims to the Department. This, naturally, made Spalding's fee collection problem more difficult and expensive.

Feeling that this course had been adopted by Vilas because of his ill will towards him, Spalding sued for the damages caused by this allegedly malicious conduct, and the libelous imputation that he was claiming fees he had not earned. Harlan, J., found all the statements in the letter fair and true, the sending of the letter "not unauthorized by law, nor beyond the scope of his official duties,"204 and asked rhetorically whether such a lawful act could be actionable "because ... what the officer did was done maliciously." 200

The argument that anyone, let alone a public official, could be liable for merely showing a statute to another, dictated a short and obvious answer. Such an act, clearly, is one which nobody can be allowed to claim as an actionable injury. However, before finding that Vilas could "not be held liable to a civil suit ... (for) duly authorized official conduct," ${ }^{208}$ the learned Justice discussed, obiter, the possibility that the heads of Executive Departments should be free of all apprehension of civil suits for damages. He cited the modern cases dealing with judges, that is, cases ignoring the historical basis of their immunity, relied heavily on the later discredited English case of Dawkins v. Lord Paulet, ${ }^{207}$ and concluded that "it could seriously cripple the proper and effective administration of public affairs as entrusted to the executive branch of government, if [Cabinet Officers] were subjected to any such restraint." 208

This case is invariably cited whenever the doctrine of immunity is imposed by a court. Yet the issue as to whether an official should be liable for his illegal acts was clearly not before the Court. It is hard to believe that if the Court had intended the case to mean more than that, where an officer acted with perfect legal sanctions, his motives were immaterial, it would not have at least discussed its several previous decisions containing directly contrary statements. ${ }^{209}$ Justice Harlan's statements, interpreted in their broad sense, are largely dependent on English authority since dis-

204 Spalding v. Vilas, 161 U.S. 483,493 (1896).

205 Ibid.

$206 \mathrm{Id}$. at 498.

${ }^{207}$ L.R. 5 Q.B. 94 (1869). See Miles v. McGrath, 4 F. Supp. 603, 605 (D. Md. 1933); "Such is the English rule, and the Court in the Vilas Case relied upon the English decisions."

208 Spalding v. Vilas, 161 U.S. 483, 498 (1896).

209 Wiikes v. Dinsman, 48 U.S. (7 How.) 89, 130 (1849); Kendall v. Stokes, 44 U.S. (3 How.) 86, 87 n.2, 788, 794 (1845); White v. Nicholls, 44 U.S. (3 How.) 266, 287 (1845), per Daniel, J.: "It is difficult to conceive how, in a society where rights and duties are relative and mutual, there can be tolerated those who are privileged to do injury legibus soluti; and still more difficult to imagine, how such a privilege could be instituted or tolerated upon the principles of social good. ..." 
credited in English law..$^{210}$ On inspection, the case appears as a shaky foundation for such a portentous doctrine.

\section{b. Growth in the Federal Courts}

Once spawned by the Supreme Court, the doctrine was nurtured carefully by the District of Columbia Court of Appeals. In a series of cases, stretching over forty years, the District of Columbia court has expanded the soinewhat innocuous circumstances of the Spalding case, to cover a multitude of sins. Malicious defamation, whether of the intragovernmental, confidential report type, ${ }^{211}$ or of the public statement species, ${ }^{212}$ wrongful prosecutions of a vicious nature, ${ }^{213}$ conspiracies to obtain convictions on perjured evidence, ${ }^{214}$ and the intentional imposition of an illegal tax for the purpose of ruining the plaintiff's business, ${ }^{215}$ have all been sheltered by this doctrine. Of greater significance, the limitation of the Spalding case to "heads of Executive departments," a restriction which at least confined this power to a group numerically small and publicity prone, was scrapped completely, so that not only Cabinet Ministers, but also officials such as United States attorneys ${ }^{216} \mathrm{FBI}$ agents, ${ }^{217}$ prison wardens, ${ }^{218}$ parole officers, ${ }^{219}$ SEC commissioners, ${ }^{220}$ assorted bureaucrats, ${ }^{221}$ and just plain policemen, ${ }^{222}$ have been allowed to claim this privilege. Swept away by such a deluge, other federal courts, with barely a nod to state law on the way, have followed the District of Columbia lead until there is now a self-contained body of more than thirty federal court cases standing for the administrative immunity doctrine. ${ }^{223}$

210 See note 155 and text at notes 146-55 supra.

211 Parravicino v. Brunswick, 69 F.2d 383 (D.C. Cir. 1934); DeArnaud v. Ainsworth, 24 App. D.C. 167, 5 L.R.A. (n.s.) 163 (1904) (see note at 163, criticizing any extension of this absolute privilege and pointing out that no other jurisdictions at that time gave such a privilege). 212 Mellon v. Brewer, 18 F.2d 168 (D.C. Cir. 1927) ; Glass v. Ickes, 117 F.2d 273 (D.C. Cir. 1940), cert. den., 311 U.S. 718 (1941).

213 Cooper v. O'Connor, 99 F.2d 135 (D.C. Cir.), cert. den., 305 U.S. 642 (1938) ; Laughlin v. Garnett, 138 F.2d 931 (D.C. Cir. 1943), cert. den., 322 U.S. 738 (1944).

214Laughlin v. Rosenman, 163 F.2d 838 (D.C. Cir. 1947).

215 Standard Nut Margerine Co. v. Mellon, 72 F.2d 557 (D.C. Cir.), cert. den., 293 U.S.

605 (1934).

216 Laughlin v. Rosenman, 163 F.2d 838 (D.C. Cir. 1947).

217 Cooper v. O'Connor, 99 F.2d 135 (D.C. Cir.), cert. den., 305 U.S. 642 (1938).

218 Lang. v. Wood, 92 F.2d 211 (D.C. Cir.), cert. den., 302 U.S. 686 (1937).

210 Ibid.

220 Jones v. Kennedy, 121 F.2d 40 (D.C. Cir.), cert. der., 314 U.S. 665 (1941).

221 Parravicino v. Brunswick, 69 F.2d 383 (D.C. Cir. 1934); Farr v. Valentine, 38 App. D.C. 413 (1912) ; DeArnaud v. Ainsworth, 24 App. D.C. 167, 5 L.R.A. (n.s.) 163 (1904).

222 Laughlin v. Garnett, 138 F.2d 931 (D.C. Cir. 1943), cert. den., 322 U.S. 738 (1944).

223 In addition to the cases cited in notes 201-22 stupra, see Taylor v. Glofelty, 201 F.2d 51 (6th Cir. 1952) (libel, federal prison physician); Papagianakis v. The Samos, 186 F.2d 257 (4tb Cir. 1950), cert. den., 341 U.S. 921 (1951) (landing permit refused, immigration officer); Springfield v. Carter, 175 F.2d 914 (8th Cir. 1949) (malicious prosecution, city building in- 
Besides the presence of a Supreme Court decision containing language lending itself to such interpretation, the growth of the immunity rule can be partly explained by its convenience as a form of judicial shorthand to dispose, at the pleading stage, cases which rather obviously have little merit. Reading behind the lines, the impression given by many of these cases is that the plaintiff's allegations of wilfulness, malice or corruption are so unlikely as to appear frivolous. ${ }^{24}$ Others have on their face alternative legal failings. ${ }^{225}$ It is doubtful if more than a few of the decisions actually resulted in hardship to the plaintiff. Several could have been explained on narrower bases of immunity. ${ }^{226}$ However, in their language, these courts have accepted as true, for demurrer purposes, accusations of gross abuses of official power, yet still maintained an absolute immunity. There is real danger that someday such language could cause great hardship for manyl

\section{c. The Reasoning of the Federal Courts}

The rationale of these courts in reaching a conclusion so far out of line with Anglo-American common-law traditions has several facets. The independence and efficiency of these officials is stressed, as only being safeguarded by complete immunity. ${ }^{227}$ The "public welfare" 228 requires that

spector); Gibson v. Reynolds, 172 F.2d 95 (8th Cir.), cert. delt., 337 U.S. 925 (1949) (malicious prosecution, draft board officer); Adams v. Home Owners' Loan Corp., 107 F.2d 139 (8th Cir. 1939) (malicious prosecution, federal government corporation) ; Phelps v. Dawson, 97 F.2d 339 (8th Cir. 1938) (malicious prosecution, state fire marshall); Brown v. Rudolph, 25 F.2d 540 (D.C. Cir.), cert. den., 277 U.S. 605 (1928) (malicious committal, lunacy commissioncr); Yaselli v. Goff, 12 F.2d 396 (2d Cir. 1926), aff'd, 275. U.S. 503 (1927) (mahicious prosecution, Ass't. U.S. Atty. Gen.) ; Block v. Sassaman, 26 F. Supp. 105 (D. Minn. 1939) (malicious alteration of records, W.P.A. official); Harwood v. McMurtry, 22 F. Supp. 572 (W.D. Ky. 1938) (hibellous report, Internal Revenue agent) ; Miles v. McGratl, 4 F. Supp. 603 (D. Md. 1933) (libel, naval officer); Anderson v. Rohrer, 3 F. Supp. 367 (S.D. Fla. 1933) (mahicious prosecution, U.S. attorney).

224 E.g., Gregoire v. Biddle, 177 F.2d 579 (2d Cir. 1949), cert. den., 339 U.S. 949 (1950); Laughlin v. Rosenman, 163 F.2d 838 (D.C. Cir. 1947); Jones v. Kennedy, 121 F.2d 40 (D.C. Cir.), cert. den., 314 U.S. 665 (1941); Standard Nut Margarine Co. v. Mellon, 72 F.2d 557 (D.C. Cir.), cert. den., 293 U.S. 605 (1934).

225 See Papagianakis v. The Samos, 186 F.2d 257 (4th Cir. 1950), cert. den., 341 U.S. 921 (1951) (no bad faith alleged); Gibson v. Reynolds, 172 F.2d 95 (8th Cir.), cert. den., 337 U.S. 925 (1949) (no unsuccessful prosecution as element of mahicious prosecution action); Miles v. McGrath, 4 F. Supp. 603 (D.Md. 1933) (stat. of limitations run); DeArnaud v. Ainsworth, 24 App. D.C. 167 (1904) (stat. of himitations run).

226 E.g., Lang v. Wood, 92 F.2d 211 (D.C. Cir.), cert. den., 302 U.S. 686 (1937) (parole bd. hearing comparable to court); Brown v. Rudolph, 25 F.2d 540 (D.C. Cir.), cert. den., 277 U.S. 605 (1928) (lunacy commissioner like a judge); Yasselli v. Goff, 12 F.2d 396 (2d Cir. 1926), aff'd, 275 U.S. 503 (1927) (prosecutor like grand jury; see text at note 239 infra).

227 Spalding v. Vilas, 161 U.S. 483, 498 (1896); Cooper v. O'Connor, 99 F.2d 135 (D.C. Cir.), cert. den., 305 U.S. 642 (1938) ; Block v. Sassaman, 26 F. Supp. 105, 108 (D. Minn. 1939) ;

Harwood v. McMurtry, 22 F. Supp. 572 (W.D. Ky. 1938).

228 Phelps v. Dawson, 97 F.2d 339, 340 (8th Cir. 1938). 
such an official should act without fear that his decisions can bring personal liability, for otherwise he will be subject to undesirable pressures which will influence his judgment and prevent "bold and forthright" public service. Since juries can be wrong, he will still suffer this enervating apprehension if lield merely to an honesty standard. ${ }^{229}$ Men of substance will be forced from public service by fear of bankruptcy, and those that enter it will have their time consumed ineffectively, coping with law suits.

Such arguments offer a wry blend of fairy tale and horror story. The picture of the unfettered public servant selflessly using his complete freedom for the good of society is heartwarming, but ignores human nature and the history of our liberties, which vividly demonstrate the apparently inevitable result of putting any unbridled powers in the hands of the executive. ${ }^{230}$ The picture of the demoralized administration, plagued by a myriad of tort actions disregards the fact that such privileges for administrative officers are found in practically no other jurisdiction in the free world, be it American state or Commonwealth or Civilian country. ${ }^{231}$ That the administration of the central government of, say, Canada, England, or Germany is, because officers in those countries are always held to standards of honesty of motive, any less "efficient," "bold" or "fearless" than its counterpart in the United States, is an unconvimcing proposition.

A possible explanation of the ability of foreign governments to operate under a more liberal rule is the universal presence in these countries of "counsel fee costs" systems which tend to eliminate the "crank" action. ${ }^{232}$ But, a remedy for this aspect of the problem could be so readily applied that its non-application is reasonably strong proof that this lack is not an essential ingredient in the growth of the immunity doctrine in the federal courts

220 See Gregoire v. Biddle, 177 F.2d 579, 581 (2d Cir. 1949), cert. den., 339 U.S. 949 (1950).

230 The words of $\mathrm{C}$. K. Allen in chiding the House of Lords for their remarkable trust of the executive, displayed in the unfortunate Liversidge v. Anderson, [1942] A.C. 206 (E.L. 1941) decision, apply equally well to the American federal judiciary. "[T]here is, apparently, something in the tranquil atmosphere of the House of Lords which stimulates faith in human nature... " See ALIEN, LAW AND ORDERS 334 (2d ed. 1956).

231The general scheme in European Civil Code nations is to give a cause of action personally against an offending officer (e.g., German Civil Code, $\$ 839$ ), but to superimpose upon this a framework of state responsibility which allows the injured party to sue the state directly for officially inflicted harms (e.g., German Constitution, Bonner Grundgesetz, art. 34). In this latter case, which is invariably chosen hy plaintiffs, the state then admonishes its officer by various means, including the right to demand indemnification where the officer's act was wilful or mabicious (e.g., German Constitution supra, German Civil Servant Code, \$23I). See Case of Laruelle, Conseil d'Etat, July 28, 1951. See also Schwartz, Public Tort Liability in France, 29 N.Y.U.L. REv. 1432, 1450 (1954).

232 For example, this may explain why, in the obviously futile field of tort suits against judicial officers for their official acts, only one such case was noted in English and Commonwealth reports during the period 1946-1956, O'Connor v. Isaacs, [1956] 2 Q.B. 288, while in the United States in the same period there were over 40 appellate decisions involving judges alone. 
of the United States. ${ }^{233}$ Moreover, if the time of administrative officials is so precious, how, logically, can they be left, as they are, exposed to trial in negligence and trespass actions? In any event, that the "public," in whose name this privilege is given, actually desires such "independence" and such "efficiency" in their servants is most doubtful. ${ }^{234}$

Another element which has received a modicum of acknowledgment by courts in their reasoning toward acceptance of the immunity rule, especially in the case of high executive officers, is the faint flavor of the Constitution and separation of powers which permeates these situations. ${ }^{236}$ The judiciary, it is argued, should not tamper in the internal functioning of a co-ordinate branch of government. Additionally, the courts appear to feel guilty that the judicial and legislative sides of government should have broad civil immunities for even corrupt and malicious acts but the executive should not. The one contention was, of course, in a democracy, necessarily settled long ago in favor of "the rule of law," Neither is a plank that can bear much weight.

The final and most important reason given in judicial explanations of the immunity is that these officials, since many of their duties involve making considered decisions, in good faith, on the merits of particular problems, are really doing what judges do, that is, exercising discretion. Judges are immune from liability for both honest and dishonest acts. $A$ fortiori, the argument runs, all officials who exercise discretion should be similarly immune. In other words, courts following this line of reasoning simply choose to treat "discretionary" as a synonym for "judicial." 238

233 At least, no court ever says that the encouragement of purely vexatious actions caused by the absence of a counsel fee costs system is one of the reasons promoting acceptance of the administrative immunity rule. If this is an unenunciated but underlying factor, then surely a poor choice is made, to give up one of the cherished principles of Anglo-American law for the sake of maintaining a system which, in this situation, appears to have self-destroyed any of its alleged advantages.

Even the most vociferous champions of the existing systen must agree that it is less harsh for a plaintiff to have to take his chances on eventually paying the defendant's counsel fee, than to force the courts to deprive him completely of any opportunity for recovery no matter how valid his case. Perhaps, if this is the situation, a 1937 Utah statute, $78 \mathrm{Utah}$ Code, ch. $11, \S 10$ (1951) which provides that attorney's fees are to be paid to the prevailing party where any law enforcement or peace officer is sued in tort for official acts, bears investigation and emulation in other jurisdictions.

${ }^{234}$ See, for an analysis of the American people's general distrust of administrative officials, Arnoxd, The Symbols of GovernMent 199-217 (1936).

235 Spalding v. Vilas, 161 U.S. 483, 498 (1896); Glass v. Ickes, 117 F.2d 273 (D.C. Cir. 1940), cert. den., 311 U.S. 718 (1941); Standard Nut Margarine Co. v. Mellon, 72 F.2d 557 (D.C. Cir.), cert. den., 293 U.S. 605 (1934) ; Mellon v. Brewer, 18 F.2d 168 (D.C. Cir. 1927). 236 See Marbury v. Madison, 5 U.S. (1 Cranch) 137 (1803) ; Powers Mereantile Co. v. Olson, 7 F. Supp. 865 (D.Minn. 1934) ; Hatfield v. Graham, 73 W. Va. 759, 81 S.E. 533 (1914); Ekern v. McGovern, 154 Wis. 157, 142 N.W. 595, 607, 611 (1913).

237 See text at notes 32-40, 91-115 supra.

238 See Royal Aquariun v. Parkinson, [1892] 1 Q.B. 431, 446, 448 (C.A.) per Fry, L.J., for English recognition of the importance of not confusing these two adjectives. 
This disregards the fact that judicial decisions are made in a completely different environment, subject to impressive procedural safeguards. It ignores the basically historical explanation of judicial immunity for dishonest acts. It forgets that the judicial order is a group numerically slight, to which, as a rule, only those with proven ability and integrity are admitted. Finally, it is illogical in that the identification applies only where certain torts are involved and not others.

The impetus to this type of reasoning came from the development of an immunity doctrine for public prosecutors. The public prosecutor, under many state constitutions, is a "judicial officer." Among his duties, he decides which criminal informations will be prosecuted. In this respect then, he performs the actual duties a grand jury traditionally performs. ${ }^{239}$ Grand juries from ancient times have shared the immunities of judges for the same historical reasons. Therefore, prosecutors could, with some show of logical ${ }^{240}$ argument, ask for the inmunity when it was alleged they had maliciously performed their "grand jury" duties.

The Second Circuit Court of Appeals, in an important decision, Yaselli v. Goff,,$^{241}$ picked up this theory approvingly from the state courts $^{242}$ in 1926, and applied it to an Assistant United States Attorney General, who had allegedly planned a complicated mahcious prosecution. The court, in sustaining the defendant's demurrer that he was immune in his activities as prosecutor, blended ideas of executive and judicial immunity to protect the defendant, although the facts alleged malice in acts in which the defendant was probably not performing "grand jury" duties. Unfortunately, prosecuting attorneys have other important duties which do not have any such connotation, so that later courts could easily overlook any intended "grand jury" or judicial explanation of his immunity, and imterpret the Yaselli court's words "that no public officer is responsible in a civil suit for a judicial determination ... however mahicious" ${ }^{243}$ to mean that no officer who exercises discretion is civilly liable for even the most corrupt actions. ${ }^{244}$

230 Segars v. State, 94 Fla. 1128, 115 So. 537 (1927); Griffith v. Slinkard, 146 Ind. 117, 44 N.E. 1001 (1896); Watts v. Gerking, 111 Ore. 641, 228 Pac. 135 (1924). For agreement by a Commonwealth court, see Powell v. Hiltgen, 5 Territories L.R. 16, 25 (Can. 1900), and for further discussion of the Commonwealth position, see Kidston, The Office of Crown Prosecutor, 32 Austl. L.J. 148 (1958).

240 Though bardly reasonable, when one recollects that the basis of this immunity as extended to corrupt and malicious judicial acts is pure ancient bistory.

24112 F.2d 396 (2d Cir. 1926), aff'd, 275 U.S. 503 (1927).

242 Griffith v. Slinkard, 146 Ind. 117, 44 N.E. 1001 (1896); Smith v. Parman, 101 Kan. 115, 165 Pac. 663 (Kan. 1917); Watts v. Gerking, 111 Ore. 641, 228 Pac. 135 (1924).

24312 F.2d 396, 403 (2d Cir. 1926), aff'd, 275 U.S. 503 (1927).

244 E.g., Hardy v. Vial, 48 Cal. 2d 577, 582, 311 P.2d 494, 496 (1957), per Gibson, C.J.: "[I]mmunity ... has been extended . . . to all ... public officers when performing . . . acts which require the exercise of discretion or judgment. ..." 
Combining this concept with the other ideas they had recently embraced, the federal courts, in the subsequent two decades, thereby, firmly moulded the immunity doctrine which today appears to flourish in these courts. ${ }^{245}$

\section{State Vieies}

To what extent have state courts adopted this doctrine of immunity? Except in the instance of the public prosecutor, the overwhelming majority of states still take the position that malice, or dishonesty of purpose, can transform an otherwise privileged act of an official into one for which liability may ensue. ${ }^{246}$

245 The $2 \mathrm{~d}, 6$ th, 8 th and D.C. Circuits make use of this doctrine Sce note 223 supra. The 4th Circuit may not yet be fully committed. See Papagianakis v. The Samos, 186 F.2d 257 (4th Cir. 1950), cert. den., 341 U.S. 921 (1951). Language in Civil lRights Act cases in the 1st and 5th Circuits, with respect to state officials at least, indicates lack of approval of the immunity doctrine. See Cobb v. City of Malden, 202 F.2d 701, 706-07 (1st Cir. 1953), per Magruder, J.; Lewis v. Brautigan, 227 F.2d 124 (5th Cir. 1955). See also Gibson v. Reynolds, 172 F.2d 95, 98 (8th Cir. 1949), for apparent rescrvations by the 8th Circuit concerning this doctrine.

Most recently, the 9th Circuit, in O'Campo v. Hardisty, 262 F.2d 621 (1959), adopted the doctrine but with considerable qualns. The court at p. 625 specifically disassociates itself from the broad reach of Gregoire v. Biddle, 177 F.2d 579 (2d Cir. 1949), note 94 supra.

The District of Columbia Court for a brief interlude displayed some disenchantment over the startling growth of its immunity Frankenstein. See Groner, J., concurring in Glass v. Ickes, 117 F.2d 273, 282 (D.C. Cir. 1940): "[It is] altogether subversive of the fundamental principle that no man in this country is so high that he is above the law. ..."; and, Edgerton, J., in Colpoys v. Gates, 118 F.2d 16, 17 (D.C.Cir. 1941), suggesting, as he refused to allow a U.S. Marshall to defame his deputies bchind such a shield, that, perhaps, the early cases "went too far." Evidently, the court subsequently overcame its qualms. See Laughlin v. Garnett and Laughlin v. Rosenman, notes 213 and 214 supra, respectively.

246 Cokb v. City of Malden, 202 F.2d 701, 707 (1st Cir. 1953); Speyer v. School District No. 1, 82 Colo. 534, 261 Pac. 859 (1927); Wadsworth v. Town of Middletown, 94 Conn. 435, 109 Atl. 246, 248 (1920); Leong Yau v. Carden, 23 Hawaii 362, 369 (1916); McCormick v. Burt, 95 Ill. 263, 266 (1880) ; Paoli v. Mason, 325 Ill. App. 197, 209, 59 N.E.2d 499, 504 (1945); Rehmann v. City of Des Moines, 204 Iowa 798, 215 N.W. 957 (1927); Tillotson v. Fair, 160 Kan. 81, 159 P.2d 471 (1945); Tanner v. Stevenson, 138 Ky. 573, 128 S.W. 878 (1910); Taulli v. Gregory, 223 La. 195, 65 So.2d 312 (1953); Donahue v. Richards, $38 \mathrm{Me.} 379$ (1854); Maurice v. Worden, 54 Md. 233, 253-56 (1880); Rocrig v. Houghton, 144 Minn. 231, 175 N.W. 542 (1919); Skeffington v. Eylward, 97 Minn. 244, 105 N.W. 638 (1906); Meinecke v. McFarland, 122 Mont. 515, 520, 206 P.2d 1012, 1014 (1949); Stephens v. Conley, 48 Mont. 352, 138 Pac. 189 (1914) ; Hester v. Miller, 11 N.J. Supcr. 264, 271, 78 A.2d 322, 326 (1951); Schwartz v. Heffernan, 304 N.Y. 474, 482, 109 N.E.2d 68, 70 (1952); State v. Swanson, 223 N.C. 442, 445, 27 S.E.2d 122, 123 (1943); Gottschalk v. Shepperd, 65 N.D. 544, 260 N.W. 573 (1935); Zimbelman v. Atkinson, 86 N.W.2d 791 (Ohio App. 1948) ; Johnson v. Moser, 181 Okla. 75, 72 P.2d 715 (1937); Petcrson v. Cleaver, 124 Ore. 547, 265 Pac. 428 (1928); Yealy v. Fink, 43 Pa. 212, 216 (1862); Atkinson v. Birmingham, 44 R.I. 123, 116 Atl. 205 (1922); State v. Farmers State Bank, 162 Tenn. 499, 505, 39 S.W.2d 281, 282 (1931); Goodwin v. Guild, 94 Tenn. 488, 492, 29 S.W. 721, 723 (1895); Hjorth v. Whittenburg, 121 Utah 324, 241 P.2d 907 (1952); Wood v. Rolfe, 128 Wash. 55, 221 Pac. 982 (1924); Hatfield v. Graham, 73 W. Va. 759,81 S.E. 533 (1914). 
Only California ${ }^{247}$ and Wisconsin ${ }^{248}$ have decisions of a general nature holding that malicious prosecution type actions cannot lie against administrative officials, and in the latter jurisdiction the cases are probably distinguishable. ${ }^{240}$

A few cases also exist where members of, or witnesses before, administrative bodies holding hearings of a court-like nature, and making decisions thereon, have been held immune for alleged malicious decisions or testimony. ${ }^{250}$ Despite general language used in some of these cases, they either are or can be explained on the basis that the administrative body involved has acted as a court in fact, and on this account, should be awarded court-like immunity. While any indiscriminate tendency to treat all administrative tribunals as court-like for immunity purposes is to be deprecated, this, at least, is far less dangerous than treating all officials who exercise discretion as judge-like for such purposes.

Defamation actions involving state officers are practically nonexistent. Among the lower echelon of officials, two cases have held slanderous remarks between police officers, concerning a suspect, as absolutely privileged, ${ }^{251}$ but, apart from the fact that both give full reports of the circumstances, clearly indicating lack of malice, the decisions in both were essentially involved with the different problem of to what extent confidential

247 See text at notes $265-68$ infra.

248 Wassermann v. City of Kenosha, 217 Wis. 223, 258 N.W. 857 (1935).

249 The Wassermam case, note 248 supra, is the leading Wisconsin case, distinguishing numerous earlier cases bolding that malice or corruption removed an official's privilege to err. But the allegation of malice against the defendant building inspector here was obviously frivolous as he acted merely pursuant to a resolution of the defendant city councilunen whose alleged malicious legislative act is protected in its turn by the privilege of legislators, not of administrators. See also Baker v. Mueller, 222 F.2d 180 (7th Cir. 1955) (special statute restricting right of action, constitutional issue); Miller v. Foster, 244 Wis. 99, 11 N.W.2d 674 (malice only surplusage, constitutional problein real issue).

There is a unique New York case which adopts the immunity language. However, the matter involved a federal government officer, the plaintiff's obvious intent was to test the constitionality of a loyalty oath provision for W.P.A. workers, and there was clearly no malice on the part of the defendant. See Lang v. Soinervell, 175 Misc. 119, 22 N.Y.S. 2d 931 (Sup., Ct. 1940). Later New York cases apparently reject this approach.

See also Nadeau v. Marchessault, 112 Vt. 309, 24 A.2d 352 (1942), where the Vermont court specifically adoptes the Spalding, Yaselli line of cases, but in a case with a very limited fact situation.

See note 247 supra.

250 Wilson v. Hirst, 67 Ariz. 197, 193 P.2d 461 (1948) (state hospital board immune for malicious decision on review of enployee's dismissal); Sweeney v. Young, S2 N.H. 159, 131 Atl. 155 (1925) (school board immune for malicious expulsion of pupil after formal hearings; but see Annot., 42 A.I.R. 763) ; Gottsclialk v. Shepperd, 65 N.D. 544, 260 N.W. 573 (1935) (state university board of trustees immune for malicious decision on employee's appeal of discharge; but university president liable for malicious evidence); Hughes v. Bizzell, 189 Okla. 472, 117 P.2d 763 (1941) (state university president's defamatory testimony to Board of Regents hearing of appeal by discharged employee held absolutely privileged).

251 Catron v. Jasper, 303 Ky. 598, 198 S.W.2d 322 (1946) ; Stivers v. Allen, 115 Wash. 136, 196 Pac. 663 (1921). 
official communications should be exposed in a court of law. ${ }^{262}$ A Michigan decision holds a State Liquor Board nember absolutely privileged in his derogatory report concerning an employee, but the court bases its decision on a special protective clause in the Liquor Board Act, and hints that without this provision the officer would be liable. ${ }^{253}$ On the other hand, several state courts in cases, containing no "exposure" problems to cloud the issue, lave declared that defamatory statements by comparable officers are actionable..$^{254}$

Of high-level officials, only a recent Pennsylvania decision ${ }^{255}$ in which the Attorney General was held absolutely privileged to call an assistant District Attorney "a communist," clearly supports the Restatement of Torts $^{256}$ assertion that such state officers are beyond the law in their official comments. In contrast, in an action against the Governor of Iowa for releasing to the press the report of the State Auditor which contained an accidental hibel of a third party, ${ }^{257}$ the court, while suggesting that releasing such public docunents to the press was, probably, an affirmative duty of

252 See Shinglemeyer v. Wright, 124 Mich. 230,82 N.W. 887 (1900) on which these cases relied. For further examples of these separate problems combining to cause difficulties see also, Michael v. Matson, 81 Kan. 360, 105 Pac. 537, 540 (1909); Maurice v. Worden, 54 Md. 233, 254 (1880); Chatterton v. Secretary of State for India, [1895] 2 Q.B. 189 (C.A.); Humphrey v. Archibald, 21 Ont. 553 (Ch. 1892); McCarthy v. City of Regina, 60 D.L.R. 205 (Sask. K.B. 1921). Sec also Street, State Secrets-A Comparative Study, 14 Modern L. Rev. 121 (1951); Carrow, Governmental Nondisclosure in Judicial Proceedings, 107 U. PA. L. REv. 166 (1958).

253 Schlinkert v. Henderson, 331 Mich. 284, 49 N.W.2d 180 (1951).

254 Pearce v. Brower, 72 Ga. 243 (1884) (road commissioner); Mayo v. Sample, 18 Iowa 306 (1865) (police commissioner); Tanner v. Stevenson, $138 \mathrm{IKy} .578,128$ S.W. 878 (1910) (school board chairman); Weber v. Lane, 99 Mo. App. 69, 71 S.W. 1099 (1903) (city councilmen).

Two cases relating to the intragovernmental communication type of defaunation (cf. the Commonwealth position, text at note 146 supra) have recently appeared. Both indicate the suability and potential liability of the state official for this kind of defamation, and his protection by a qualified privilege only. See Hood v. State, 181 N.I.S.2d 621, 626 (Ct. Cl. 1958); Vigoda v. Barton, 155 N.E.2d 409 (Mass. 1959).

255 Matson v. Margiotti, $371 \mathrm{~Pa} .188$, 88 A.2d 892 (1952), a 3-2 decision, in which Jones, J., in a strong dissent commenting on the attorney general's issuing his defamatory letter directly to the press, suggests at 902 that if this is permissible, "the doctrime . . . will be extended far beyond any conscionable limits and become an aid to persecution in the hands of the unserupulous. ..." The majority, finding no Pennsylvania authority for its position, relies entirely on the line of federal decisions.

And see, contra, Jacobs v. Herlands, 17 N.Y.S.2d 711 (Sup. Ct.), aff'd, 19 N.Y.S. 2d 770 (1940), where New York's Commissioner of Investigation was denied any such privilege for a defamatory press release.

256 Restatement, TorTs $\$ 591$ (1938). Nor do the Restaters in their notes to this section offer any state cases in support of this assertion. See RESTATEMENT, TORTS, Explanatory Notes $\S 1033$, at 212 (Tent. Draft No. 13, 1936). They rely principally on the Spalding and Chatterton decisions, notes 202,252 supra.

257 Ryan v. Wilson, 231 Iowa 33, 300 N.W. 707 (1941). 
the Governor for which he could not be held liable, ${ }^{258}$ made its decision on the basis that the Governor had only a qualified privilege, but that the plaintiff had not proved malice. Otherwise, that high executive officers of states have, because of their exalted position, any special immunity from personal civil liability for injury caused by the malicious or corrupt use of their offices, is suggested by one confusing Georgia case only, ${ }^{259}$ and negatived by the words of several others, including cases involving the highest state executive officer, the governor. ${ }^{260}$

Even the immunity of the public prosecutor is by no means universally accepted by state courts, and where accepted it would appear to be so on a more discriminating basis than in the federal courts. At least five jurisdictions, New Jersey, Minnesota, Massachusetts, Florida and Hawaii, apparently, refuse to allow the office to offer a shield to the prosecutor from civil retribution for malicious acts done in the course of performing his office. $^{261}$ Seemingly, in another thirty jurisdictions the question has never been litigated. A majority of the cases in state courts accepting the immunity doctrine have involved allegations of malice in the performance of the prosecutor's "grand jury" duties, that is, in his decision whether or not to press prosecution of the complaint of another. ${ }^{262}$ Thus, it seems

258 The distinction here is that a governor (or other officer) may be under a legal or customary duty to publish the official reports of another state officer for whose statements he can hardly be held responsible. The point which some courts have missed, is that this does not suggest that the real authors of the defamatory statements (including the officer who makes the report public if he is the author) are absolutely privileged.

250 Askew v. Bassett Furniture Co., 172 Ga. 723, 158 S.E. 577 (1931) (malicious petition for bankruptcy, state supernitendent of banks).

260 Garden City v. Nation, 83 Kan. 237, 109 Pac. 772, 773 (1910) (state auditor); State v. Farmers State Bank, 16 Tenn. 499, 505, 39 S.W.2d 281, 282 (1931) (state superintendent of banks) ; Hatfield v. Graham, 73 W.Va. 759, 81 S.E. 533 (1914); Ekern v. McGovern, 154 Wis. 157, 223, 142 N.W. 595, 613 (1913) (Governor).

261 Leong Yau v. Carden, 23 Hawaii 362 (1916) ; Parker v. Huntington, 2 Gray 124 (Mass. 1854); Buhner v. Reusse, 144 Minn. 45, 175 N.W. 1005 (1920); Earl v. Winne, 14 N.J. 119, 134, 101 A.2d 535, 543 (1953); Lewis v. Brautigan, 227 F.2d 124 (5th Cir. 1955) (by implication).

262 Prentice v. Bertken, 50 Cal. App. 2d 344, 123 P.2d 96 (1942); Pearson v. Reed, 6 Cal. App. 2d 277, 44 P.2d 592 (1935); Griffith v. Slinkard, 146 Ind. 117, 44 N.E. 1001 (1896); Smith v. Parman, 101 Kan. 115, 165 Pac. 663 (1917); Potash v. Sacks, 123 N.Y.S.2d 913 (Sup. Ct. 1953); Price v. Cook, 120 Okla. 105, 250 Pac. 519 (1926); Watts v. Gerking, 111 Ore. 641, 228 Pac. 135 (1924); Mitchelle v. Steele, 29 Wasl.2d 473, 236 P.2d 349 (1951); semble, Cawley v. Warren, 216 F.2d 74 (7th Cir. 1954). And see dissent of Burr, J., in Kittler v. Kelsch, 56 N.D. 227, 216 N.W. 898 (1927).

On the other hand, see Norton v. Hoffman, 34 Cal. App. 2d 189, 93 P.2d 250 (1939); Kittler v. Kelsch, 56 N.D. 227,216 N.W. 898 (1927) where the courts reject this distinction and exempt prosecutors who personally have initiated the proceedings involved. See Prosser, TORTS 649 (2d ed. 1955). Quaere, whether Norton v. Hoffman, supra, is not subject to re-examination in the light of the very recent Cahifornia district court of appeal decision in Oppenheimer v. Tamblyn, 167 A.C.A. 179, 334 P.2d 152 (1959). 
reasonable to suppose that state courts, unlike the federal courts, ${ }^{203}$ will distinguish between circumstances when the prosecutor was acting as a "grand jury" and when as something else, say a policeman, and allow him imniunity for malicious prosecution only on the former occasions, holding him to the same standard as a private citizen when he is the initiator of the proceedings. ${ }^{204}$

California stands alone among the states as having a substantial body of case law which adopts the federal courts' approach of extended immunity to administrative officers. There, in spite of vigorous and unceasing criticism by the late Justice Carter, the supreme court has handed a carte blanche to indulge in malicious prosecution to such exalted and vital public servants as municipal building imspectors, ${ }^{205}$ game wardens ${ }^{200}$ and policemen. ${ }^{267}$ A recent decision, Hardy v. Vial, ${ }^{268}$ dispels any doubt that the im-

203 E.g., Laughlin v. Rosenman, 163 F.2d 838 (D.C. Cir. 1947); Ravenscroft v. Casey, 139 F.2d 776 (2d Cir.), cert. den., 323 U.S. 745 (1944); Laughlin v. Garnett, 138 F.2d 931 (D.C. Cir. 1943), cert. den., 322 U.S. 738 (1944); Yaselli v. Goff, 12 F.2d 396 (2d Cir. 1926), a.fगd, 275 U.S. 503 (1927).

264 However, the RESTATEMENT, ToRTs §656 (1938) does not recognize this distinction. It is interesting to note that this whole doctrine extending such unusual immunities to a public official appears to stem from the Indiana case of Griffith v. Slinkard, 146 Ind. 117, 44 N.E. 1001 (1896) (on which, inter alia, the Restaters rely) in which the court, misled by a headnote perhaps, relied as authority on a complete misinterpretation or misreading of the Massachusetts case of Parker $v$. Huntington, note 261 supre, which, in fact, suggests the opposite result.

265 Dawson v. Martin, 150 Cal. App. 2d 379, 309 P.2d 915 (1957); White v. Brinkman, 23 Cal. App. 2d 307, 73 P.2d 254 (1937).

260 White v. Towers, 37 Cal. 2d 727, 738, 235 P.2d 209, 216 (1951). "[A] major step toward statism," said Carter, J., in his dissent. This case, a 4-3 decision, is the inspiration of the recent surge of "immunity" decisions in the California courts, after the doctrine of White ข. Brinkman, note 265 supra, had lain dorniant for 15 years. It was, perhaps, a response to the "exclusionary evidence rule verstus police efficiency" dispute, then going on in California.

267 Coverstone v. Davies, 38 Cal.2d 315, 327, 239 P.2d 876, 883 (1952). "[P]olice state philosophy," dissented Carter, J. See Griswold v. Hollywood Turf Club, 106 Cal. App. 2d 578, 235 P.2d 656 (1951), where on the first occasion subsequent to White v. Towers, note 266 supra, that the issue of malicious prosecution by a police officer arose, the immunity doctrine was ignored.

Decisions in other jurisdictions, except of course the federal ones, are unanimous in holding that police offcers are subject to liability for malicious prosecution. See, e.g., Taulli v. Gregory, 223 La. 195, 65 So.2d 312 (1953); Motley v. Dugan, 191 S.W.2d 979 (Mo. App. 1945); Atkinson v. Birmingham, 44 R.I. 123, 116 Atl. 205 (1922); Neff v. Palmer, 66 Ohio L. Abs. 590, 118 N.E.2d 719 (C.P. 1953); Petersen v. Cleaver, 124 Ore. 547, 265 Pac. 428 (1928); Kidd v. Reynolds, 20 Tex. Civ. App. 355, 50 S.W. 600 (1899) ; O'Hara v. Sears Roebuck, 286 App. Div. 104, 142 N.Y.S.2d 465 (1955); Neczypor v. Jacobs, 188 Pa. Super. 25, 146 A.2d 83 (1958).

The California courts drew the line at extending this dostrine to police officers making falso arrests. See, Miller v. Glass, 44 Cal.2d 359, 282 P.2d 501 (1955) (game warden); Dragna v. White, 45 Cal. $2 \mathrm{~d} 469,289$ P.2d 428 (1955) (police). This seems anomalous, as, on the merits, it would seem that a peace officer making an honest but mistaken estimate of the existence of reasonable cause for arrest is more deserving than one who deliberately abuses the processes of the law for corrupt or malicious ends. It is difficult to see what Davis, Adninistrative Officers' Tort Liability, 55 MicH. L. REv. 201, 215, 216 (1956) finds "especially enlightening" and "valiant" about this line of cases.

20848 Cal. 2d 577, 311 P.2d 494 (1957). But see Carter, J., dissenting at 586; [S]uch a result ... lead[s] to more, rather than less, dishonesty on the part of public officials . ..." 
munity might be restricted only to officials involved in criminal prosecution or investigation. ${ }^{269}$ Notwithstanding allegations of a particular unsavory schenie among various state college and department of education officials to cause the plaintiff professor's disgrace and dismissal, the court sustained the official defendants' demurrer, pointing to the federal decisions which extend immunity "to all executive public officers when performing within the scope of their power acts which require the exercise of discretion."270 Although a case requiring such a decision has, as yet, not clearly arisen, there can be little doubt that this court will extend immunity to public officers for their defamatory statements. ${ }^{2 \pi 1}$

\section{Conclustons}

Any further erosion of the majority common law position of personal responsibility of public officers for conduct of this nature would be unfortunate. To argue that what is needed in Anglo-American jurisdictions is the development of a doctrine of general liability of the state to replace the personal liability of officers for injurious official acts is constructive and vahid. But to advocate the latter without the former seems completely unreasonable if the underlying need for such a change is to increase the individual's protection from injuries inflicted by the social machine. While the 21 st century may see much inore efficient and fairer loss compensation methods developed for dealing with such injuries, in the meantime, and in the absence of such schemes, the citizen, as a minimum, requires the protection of civil sanctions to enforce impartial and non-malicious treatment by public officials.

In addition, because our slowly developing governmental liability legislation is framed so as to maintain the necessity of personal liability of a public officer before state liability arises, any common law extension of personal immunity of public officers is doubly unfortunate. The effect is that, even where such hard-gained legislative reform has been obtained, the state as well as the officer is, once again, made immune, ${ }^{272}$ and the injustice of leaving injured parties entirely without compensation, forced to bear privately a loss occasioned by a breakdown of the mechanics of the state, is continued.

Justice Carter suggested that "the entire doctrine of . . immunity . . . should be placed in the judicial garbage can where it belongs." ${ }^{273}$ This would

269 See also Oppenheimer v. Arnold, 99 Cal. App. 2d 872, 222 P.2d 940 (1950) (malice claimed by wrongfully dismissed employee).

$27048 \mathrm{Cal} .2 \mathrm{~d}$ at 582,311 P.2d at 496.

271 See Car. Crv. Code $\$ 47(1)$.

272 See Fishbein v. State, 120 N.Y.S.2d 92 (Ct.Cl. 1953) (state not liable for judge caused injury); semble, Thompson v. Williams, 32 N.S.W. Weekly No. 27 (1914) (magistrate).

273 Dissenting in Hardy v. Vial, 48 Cal.2d 577, 587, 311 P.2d 494, 499 (1957). 
seem an appropriate spot, at least until we have adopted a policy of complete state responsibility for all officially inflicted injuries, a policy which includes also some definite substitute safeguards against official personal irresponsibility ${ }^{274}$ Meanwhile, there is a danger that in spite of the barren reasoning of such decisions, the mere flow and easy access of the federal cases extending immunity will persuade more state courts to follow. . $^{275}$ While careful analysis of the federal decisions usually uncovers more acceptable alternative explanations of these cases than later federal courts have been willing to find, and thus mitigates their sting, what is sorely needed is a United States Supreme Court decision explaining Spalding v. Vilas $^{276}$ and reaffirming older cases. The Supreme Court has never again, since the Spalding case, taken occasion to face squarely the problem of the tort liability of the malicious federal officer. ${ }^{277}$ The present Court, it is suggested, would be unlikely to look with a favorable eye on a doctrine which protects arbitrary officials from tort liability for illegal acts. ${ }^{278}$ In the future, all American courts when faced with the pleas of public officers for special immunities from civil liability for corrupt or malicious acts, should recollect the words of Baron Eyre that "men of honour will do their duty and will abide the consequences," 270 and reject such claims.

\section{RÉSUMÉ}

Essentially what is needed in this field is an entirely new approach on how to distribute the losses caused to individuals by the state. However, for the foreseeable future, even in those jurisdictions having governmental tort hability statutes, the Anglo-American system of recovery seems to be centered on the individual public officer involved and whether his act constituted an actionable tort.

274 See Schwartz, Public Tort Liability in France, 29 N.Y.U.L. REv. 1432, 1450 (1954); Laski, Responsibility of the State in England, 32 HARv. L. REv. 447, 458 (1919).

275 Cases such as Matson v. Margiotti, $371 \mathrm{~Pa} .188,88$ A.2d 892 (1952) (sce note 255 supra) ; Nadeau v. Marchessault, 112 Vt. 309, 24 A.2d 352 (1942) (poor overseer, malicious nonfeasance); Johnson v. State Board of Morticians, 288 S.W.2d 214 (Tex. Civ. App. 1956) (board investigator), indicate that other states may be ready to join California along this primrose path.

276161 U.S. 483 (1896).

277 However, see Nalle v. Oyster, 230 U.S. 165 (1913) where the Court refused to allow District of Columbia School Board officials any absolute privilege in a defamation action brought by a school teacher. See also 275 U.S. 503 (1927), where Yaselli v. Goff, 12 F.2d 396 (2d Cir. 1926), was affirmed, per curiam, in one sentence, on the basis of two Supreme Court decisions involving bigh court judges.

278 See Justice Frankfurter's comment im his dissent to Great Northern Ins. Co. v. Read, 322 U.S. 47, 59 n.2 (1944), that Dicey's statement concerning the personal responsibility of officials "was an idealization of actuality. But in the perspective of our time its validity as an ideal has gained and not lost."

279 Sutton v. Johnstone, 1 T.R. 494, 504, 99 Eng. Rep. 1215, 1222 (K.B. 1786), rev'd on other grounds at 1 T.R. 510, 99 Eng. Rep. 1225 (Ex. Ch. 1876). 
Of the various categories of public officers, the head of state is necessarily completely immune from being questioned in court during his term of office for acts done both in his official role and in his personal life. Judges, by definition not liable for honest error, are, due to ancient and almost forgotten explanations, immune civilly for corrupt or malicious official acts. Legislators for historical reasons have immunity in what they say as legislators, and for valid theoretic reasons cannot be questioned for the laws they make. On the other hand, executive and administrative officials are generally liable personally for tortious conduct in the course of their duties.

Honesty of motive, in almost all English and American jurisdictions, is the minimum requirement of official acts. There is a body of decisions in the federal courts of the United States which holds that administrative officials, no matter what their motives, cannot be held for certain torts in which motive is a key element. This is, however, a minority viewpoint, resting on extremely fragile foundation, and apparently, with one notable exception, unable to gain any consistent adherents in state ranks or elsewhere. 